\title{
Original paper \\ Pošepnýite, a new Hg-rich member of the tetrahedrite group from Př́bram, Czech Republic
}

\author{
Pavel ŠKÁCHA ${ }^{1,2}$, Jiří SEJKORA²*, Jakub PLÁŠIL ${ }^{3}$ Emil MAKOVICKY \\ ${ }^{1}$ Mining muzeum Přibram, Hynka Kličky place 293, Přibram VI, 261 01, Czech Republic \\ 2 Department of Mineralogy and Petrology, National Museum, Cirkusová 1740, Prague 9-Horní Počernice, 193 00, Czech Republic, \\ jiri_sejkora@nm.cz \\ ${ }^{3}$ Institute of Physics ASCR, v.v.i., Na Slovance 1999/2, 18221 Praha 8, Czech Republic \\ ${ }^{4}$ Institute for Geoscience and Natural Resources Managment, University of Copenhagen, Østervolgade 10, DK-1350, Copenhagen K, \\ Denmark \\ * Corresponding author
}

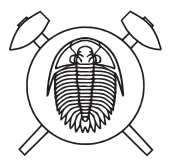

The new mineral pošepnýite was found in the mine dump of the shaft No. 16 Háje, one of the mines in the Př́ibram uranium and base-metal district, central Bohemia, Czech Republic. Pošepnýite is associated with př́bramite, dzharkenite, ferroselite, hakite-( $\mathrm{Hg})$, tetrahedrite-( $\mathrm{Zn})$, antimonselite and uraninite in a calcite-dominant gangue. The new mineral occurs as idiomorphic to hypidiomorphic grains up to $100 \mu \mathrm{m}$ in size. Pošepnýite is steel-grey and has a metallic lustre. Mohs hardness is $c a$. 3.5-4; the calculated density is $6.23 \mathrm{~g} \mathrm{~cm}^{-3}$. In reflected light, pošepnýite is light brown. No bireflectance, pleochroism, anisotropy or internal reflections were observed. The average empirical formula, based on electron-microprobe analyses (62 spot analyses), is $\left(\mathrm{Cu}_{3.33} \mathrm{Ag}_{0.28}\right)_{\Sigma 3.61}\left(\mathrm{Hg}_{3.43} \mathrm{Cu}_{2.50} \mathrm{Zn}_{0.03} \mathrm{Cd}_{0.03} \mathrm{Fe}_{0.01}\right)_{\Sigma 6.00}\left(\mathrm{Sb}_{3.88} \mathrm{As}_{0.12}\right)_{\Sigma 4.00}$ $\left(\mathrm{Se}_{10.83} \mathrm{~S}_{1.29}\right)_{\Sigma 12.12}$. The ideal formula is $\left(\mathrm{Cu}_{3+x}^{+} \square_{3-x}\right)_{\Sigma 6}\left(\mathrm{Hg}^{2+}{ }_{4-x} \mathrm{Cu}^{+}{ }_{2+x}\right)_{\Sigma 6} \mathrm{Sb}_{4}\left(\mathrm{Se}_{12.5} \square_{0.5}\right)_{\Sigma 13}, 0 \leq x<<2$, which requires $\mathrm{Cu}$ 12.25, $\mathrm{Hg} 30.93$, Sb 18.77 and Se 38.05, total 100.00 wt. \% (for $x=0$ ) or Cu 17.65, Hg 23.87, Sb 19.32, Se 39.16, total 100.00 wt. \% (for $x=1$ ). Pošepnýite is cubic, $I-43 m, a=10.964(1) \AA$, with $V=574.82(15) \AA^{3}$ and $Z=2$. The strongest reflections of the calculated powder X-ray diffraction pattern are $[d, \AA$ (I) $(h k l)]$ are: 3.165(100) (222), 2.930(24) (321), 2.0017(16) (521), 1.9381(65) (440), 1.6528(31) (622)]. According to the single-crystal X-ray diffraction data $\left(R_{\mathrm{obs}}=0.051\right)$, pošepnýite is isostructural with minerals of the tetrahedrite group. The cubic structure of pošepnýite is a tetrahedral framework with cavities and a part of tetrahedra replaced by $\mathrm{SbSe}_{3}$ coordination pyramids. It has one type of pyramidal $\mathrm{Sb}$ position, one type of tetrahedrally coordinated cation position $\mathrm{M} 1$ occupied by $(\mathrm{Hg}, \mathrm{Cu})$, and one type of partly vacant cation site $M 2$ with triangular coordination. The main anion site Se1 participates in all of these cation coordination polyhedra. Minority anion 'Se2' ties the six coordination triangles of $\mathrm{Cu} 2$ in the cavity of the tetrahedral framework into one cluster. Pošepnýite is named after the František Pošepný, a famous $19^{\text {th }}$-century geologist, often regarded as the father of the modern economic geology.

Keywords: pošepnýite, new mineral, tetrahedrite group, crystal structure, uranium deposit, Př́bram

Received: 20 April 2020; accepted: 3 August 2020; handling editor: F. Laufek

The online version of this article (doi: 10.3190/jgeosci.308) contains supplementary electronic material.

\section{Introduction}

Pošepnýite is a new $\mathrm{Cu}-\mathrm{Sb}-\mathrm{Hg}-\mathrm{Se}$ mineral of the tetrahedrite group. It is a part of a complex selenide assemblage at the abandoned Príbram uranium and base-metal ore district, central Bohemia, Czech Republic. It was found in material from mine dump of the shaft \#16 (Háje). Shaft No. 16 mined the Bytíz, Jerusalem and Háje deposits, especially in the middle and deep parts. The Bytíz deposit was the most important deposit within the Príbram uranium and base-metal district; it produced more than $52 \%$ of the uranium from the whole district. The Príbram uranium and base-metal district is the largest vein-type uranium deposit in the Czech Republic (Litochleb et al. 2003, 2004).

The new mineral and the name were approved by the Commission on New Minerals, Nomenclature and Clas- sification of the International Mineralogical Association (IMA 2018-121a). The cotype material (two polished sections) is deposited in the Mineralogical Collection of the Department of Mineralogy and Petrology of the National Museum, Prague, Czech Republic (catalogue number P1P 15/2015) and in the Mineralogical Collection of the Mining Museum Př́bram, Př́bram, Czech Republic, under the catalogue number $1 / 2016$.

František Pošepný (30. 3. 1836-27. 3. 1895) was born in Jilemnice (nowadays in the Czech Republic). After graduating from Př́bram Mining College, he worked as a mining trainee while studying at the Imperial Geological Institute in Vienna. In 1870, he was appointed to the position of chief geologist for Hungary and conducted research on the Slovak deposits. Four years later, he returned to Vienna and served as vice-chancellor at the 
former Ministry of Agriculture. In addition to his research in Austria, he visited various deposits in Nevada and California. In 1879 he returned to Př́bram, where he headed the School of Economic Geology, and during this period he continued his research around the Př́bram district.

$\mathrm{He}$ is considered to be a founder of modern economic geology. His most famous work is ,The Genesis of Ore Deposits“ (Pošepný 1893). He published about 100 papers especially devoted to gold deposits. The name "Pošepnyt" was used in the past for a poorly defined hydrocarbon from San Francisco (Bayliss 2000), lastly, in 1939.

\section{Occurrence}

The Př́ibram ore area (central Bohemia, Czech Republic) is known for deposits of base-metals as well as for uranium ores. It can be divided into two main ore districts: the Březové Hory base-metal ore district and the complex Příbram uranium
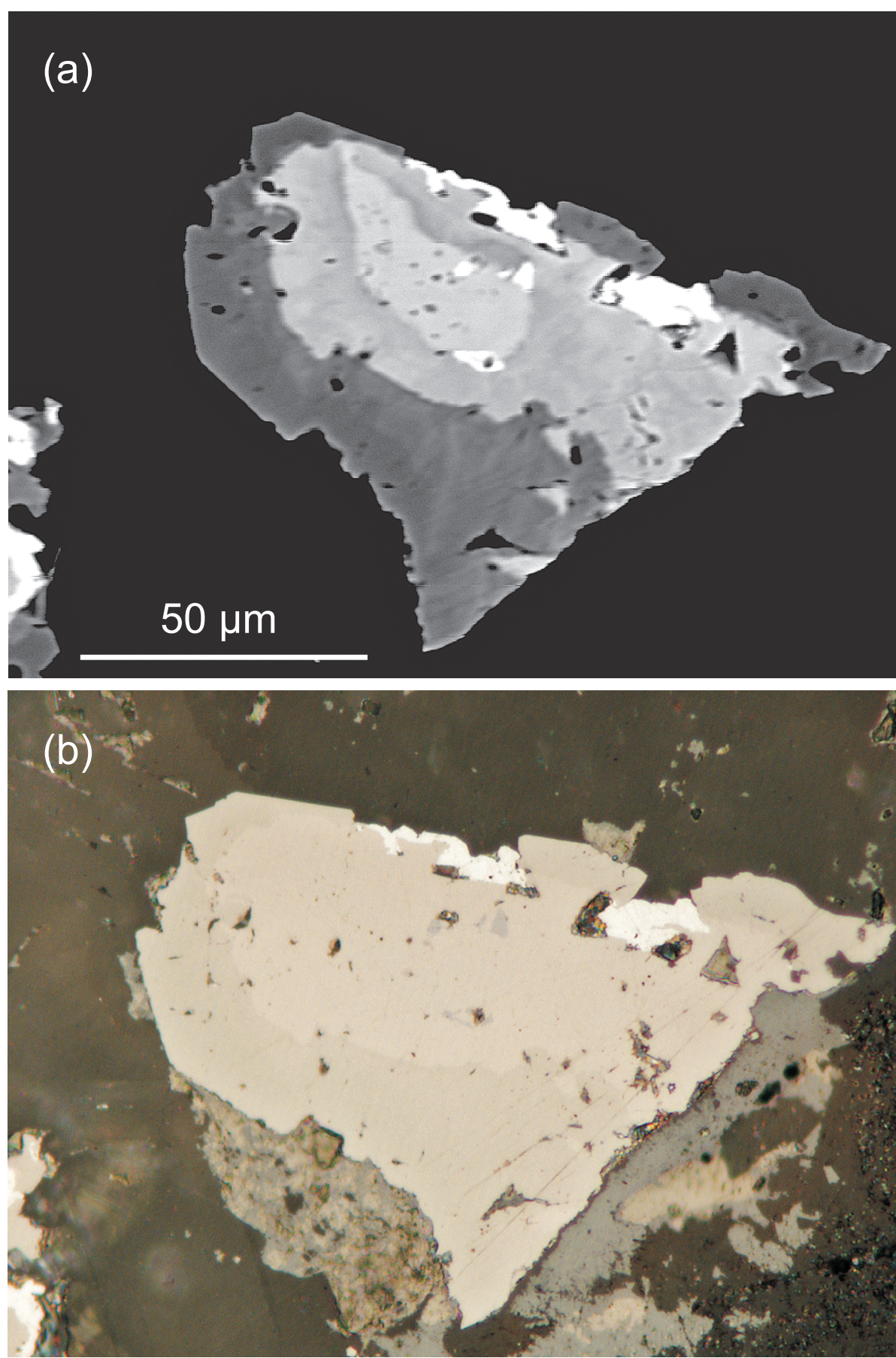
and base-metal district. The latter represents the most significant accumulation of veintype hydrothermal U-ores in the Czech Republic and world-class deposits of this type. The hydrothermal $U$ mineralization of late Variscan age is related to a $1-2 \mathrm{~km}$ wide and almost $25 \mathrm{~km}$ long zone formed by a strongly tectonized series of Upper Proterozoic rocks following the contact with granitoids of the Permo-Carboniferous Central Bohemian Plutonic Complex.

The Př́ibram uranium and base-metal district can be subdivided into several ore deposits (also termed ore nodes) - among them the most important were Bytíz, Háje and Brod (Ettler et al. 2010). In this ore district, there are four main mineralization stages (1) siderite-sulfidic; (2) calcite; (3) calcite-uraninite; (4) calcite-sulfidic. Selenide mineralization occurs in close association with uraninite of the calcite-uraninite mineralization stage, but selenides are always younger than uraninite. It is uncertain whether the selenides at Príbram formed at the end of the calcite-uraninite stage or the

Fig. 1a: The grain of pošepnýite (light grey) partly replaced by younger $\mathrm{Hg}$ hakite (medium grey), hakite is partly replaced by the youngest $\mathrm{Zn}$-tetrahedrite (dark grey); chemical inhomogeneity of hakite and tetrahedrite is caused primarily by $\mathrm{SeS}_{-1}$ substitution. The oldest white inclusions comprise tiemannite and clausthalite. BSE photo; b: the same grain in reflected light. 
Fig. 2 Reflectivity curves for pošepnýite and hakite. Elevated Hg content probably causes the reflectivity difference between pošepnýite and hakite.

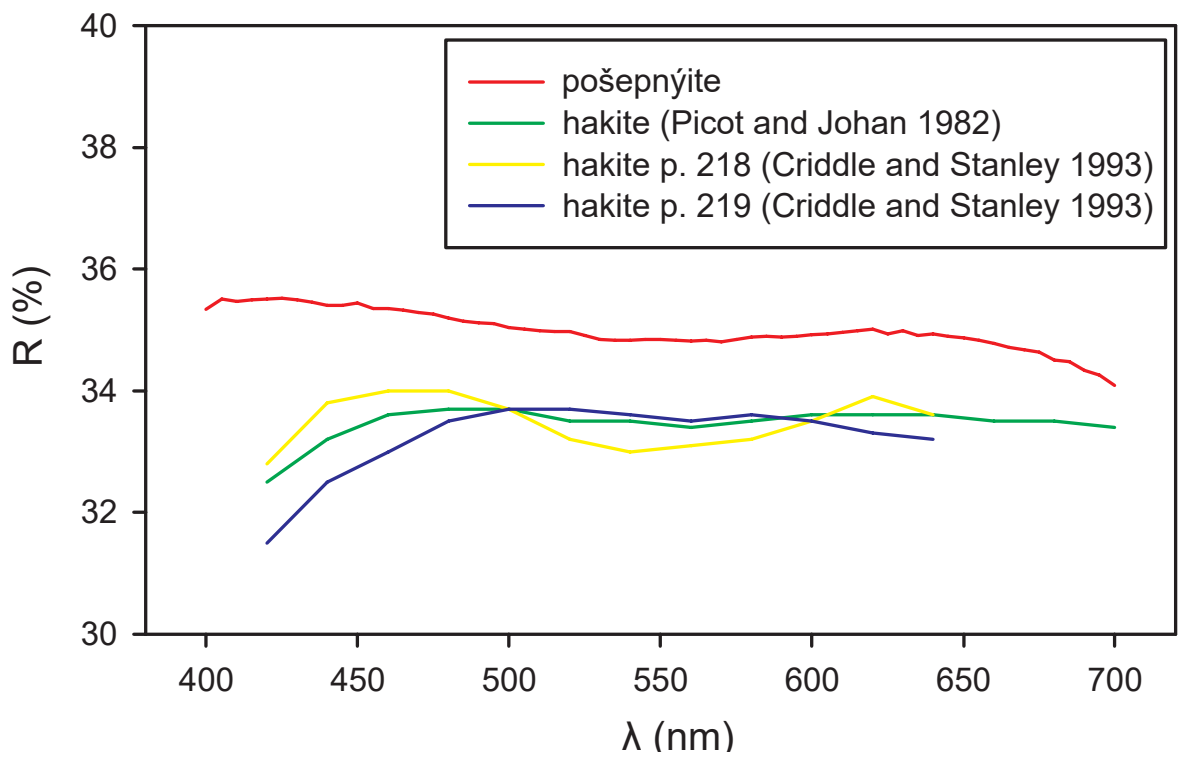

The majority of the selenide-bearing material probably came from the ore deposit Bytíz. The Se-U mineralization is of low-temperature hydrothermal origin and is confined to calcite veins with a thickness varying from tens of centimeters to several meters. The principal ore is represented by uraninite, while younger pyrobitumen predominates in deeper parts of the deposit.

Pošepnýite forms microscopic grains in the close association with antimonselite, dzharkenite, ferroselite, př́ibramite, tiemannite, hakite- $(\mathrm{Hg})$, tetrahedrite-( $\mathrm{Zn})$ and uraninite in a calcite gangue.

\section{Physical and optical properties}

Pošepnýite forms idiomorphic to hypidiomorphic grains up to $100 \mu \mathrm{m}$ in size (Fig. 1). The mineral is steel grey and is opaque in transmitted light; it has a metallic luster. No cleavage nor fracture was observed. The calculated density $(Z=2)$ for the empirical formula is $6.23 \mathrm{~g} / \mathrm{cm}^{3}$. Mohs hardness is assumed to be 3.5-4 by analogy with minerals of the tetrahedrite group. In reflected light, pošepnýite is light brown; pleochroism, anisotropy and internal reflections were not observed. Reflectance percentages (air) for the four COM wavelengths $(R)$ for pošepnýite from Př́ibram are: $35.3(470 \mathrm{~nm}), 34.8(546 \mathrm{~nm}), 34.9(589 \mathrm{~nm})$ and 34.9 $(650 \mathrm{~nm})$. The full set of reflectance data (spectrophotometer MSP400 Tidas at Leica microscope, objective 50×, WTiC standard in the air) is given in Tab. 1 and Fig. 2.

\section{Chemical composition}

Chemical analyses $(n=62)$ were performed using a Cameca SX100 electron microprobe (National Museum, 
Tab. 2 Chemical data for pošepnýite

\begin{tabular}{|c|c|c|c|c|}
\hline Constituent & wt. $\%$ & Range & $\mathrm{SD}$ & Probe standard (line) \\
\hline $\mathrm{Ag}$ & 1.21 & $0.77-1.53$ & 0.17 & $\operatorname{Ag}\left(L_{\alpha}\right)$ \\
\hline $\mathrm{Cu}$ & 14.95 & $11.94-19.29$ & 1.80 & $\mathrm{CuFeS}_{2}\left(K_{\alpha}\right)$ \\
\hline $\mathrm{Hg}$ & 27.74 & $23.15-30.94$ & 2.12 & $\operatorname{HgTe}\left(M_{\alpha}\right)$ \\
\hline $\mathrm{Fe}$ & 0.03 & $0.00-0.27$ & 0.06 & $\mathrm{FeS}_{2}\left(K_{\alpha}\right)$ \\
\hline $\mathrm{Cd}$ & 0.12 & $0.00-0.40$ & 0.10 & $\operatorname{CdTe}\left(L_{\alpha}\right)$ \\
\hline $\mathrm{Tl}$ & 0.03 & $0.00-0.36$ & 0.08 & $\mathrm{Tl}(\mathrm{BrI})\left(L_{\alpha}\right)$ \\
\hline $\mathrm{Zn}$ & 0.08 & $0.00-0.39$ & 0.08 & $\mathrm{ZnS}\left(K_{\alpha}\right)$ \\
\hline $\mathrm{Sb}$ & 19.06 & $17.72-20.60$ & 0.61 & $\mathrm{Sb}_{2} \mathrm{~S}_{3}\left(L_{\alpha}\right)$ \\
\hline As & 0.37 & $0.00-0.84$ & 0.29 & $\operatorname{NiAs}\left(L_{\alpha}\right)$ \\
\hline $\mathrm{Se}$ & 34.51 & $31.48-36.12$ & 0.83 & $\operatorname{PbSe}\left(L_{\alpha}\right)$ \\
\hline $\mathrm{S}$ & 1.66 & $0.83-2.70$ & 0.44 & $\mathrm{FeS}_{2}\left(K_{\alpha}\right)$ \\
\hline Total & 99.74 & & & \\
\hline
\end{tabular}

SD - standard deviation

Prague) operating in wavelength-dispersive mode $(25 \mathrm{kV}$, $20 \mathrm{nA}$ and $2 \mu \mathrm{m}$ wide beam). The following standards and $\mathrm{X}$-ray lines were used to minimize line overlap: $\operatorname{Ag}\left(\operatorname{Ag} L_{\alpha}\right), \mathrm{Au}\left(\mathrm{Au} M_{\alpha}\right), \mathrm{Bi}\left(\mathrm{Bi} M_{\beta}\right), \mathrm{CdTe}\left(\mathrm{Cd} L_{\alpha}\right), \mathrm{Co}$
$\left(\mathrm{Co} K_{\alpha}\right)$, chalcopyrite $\left(\mathrm{Cu} K_{\alpha}\right)$, $\mathrm{FeS}_{2}\left(\mathrm{Fe} K_{\alpha}, \mathrm{S} K_{\alpha}\right), \operatorname{HgTe}\left(\operatorname{Hg} M_{\alpha}\right)$, $\mathrm{NiAs}\left(\mathrm{Ni} K_{\alpha}, \mathrm{As} L_{\alpha}\right), \mathrm{PbS}\left(\mathrm{Pb} M_{\alpha}\right)$, $\mathrm{PbSe}\left(\mathrm{Se} L_{\alpha}\right), \mathrm{PbTe}\left(\mathrm{Te} L_{\alpha}\right), \mathrm{Sb}_{2} \mathrm{~S}_{3}$ $\left(\mathrm{Sb} L_{\alpha}\right), \mathrm{Tl}(\mathrm{BrI})\left(\mathrm{Tl} L_{\alpha}\right)$ and $\mathrm{ZnS}$ $(\mathrm{ZnK \alpha})$. Peak counting times were $20 \mathrm{~s}$ for all elements and one half of the peak time for each background. Other elements, such as $\mathrm{Au}, \mathrm{Bi}, \mathrm{Cd}, \mathrm{Co}$, $\mathrm{Ni}, \mathrm{Pb}, \mathrm{Te}, \mathrm{Tl}$, and $\mathrm{Zn}$ were found to be below the detection limits $(0.02-0.05$ wt. \%). Raw intensities were converted to the concentrations of elements using the automatic „PAP” (Pouchou and Pichoir 1985) matrix-correction software. Analytical data are given in Tab. 2, and representative analyses covering all variations of $\mathrm{Hg}$ contents are given in Tab. 3 .

Tab. 3 Representative set of analyses for pošepnýite (in wt. \%)

\begin{tabular}{|c|c|c|c|c|c|c|c|c|c|c|c|c|c|c|}
\hline & 1 & 2 & 3 & 4 & 5 & 6 & 7 & 8 & 9 & 10 & 11 & 12 & 13 & 14 \\
\hline $\mathrm{Ag}$ & 1.27 & 1.25 & 1.30 & 1.34 & 1.36 & 1.35 & 1.35 & 1.43 & 1.53 & 1.20 & 1.26 & 1.52 & 1.25 & 1.51 \\
\hline $\mathrm{Fe}$ & 0.00 & 0.00 & 0.00 & 0.00 & 0.14 & 0.00 & 0.00 & 0.00 & 0.00 & 0.07 & 0.00 & 0.07 & 0.08 & 0.06 \\
\hline $\mathrm{Cd}$ & 0.00 & 0.09 & 0.00 & 0.00 & 0.00 & 0.00 & 0.07 & 0.00 & 0.00 & 0.00 & 0.21 & 0.00 & 0.22 & 0.00 \\
\hline $\mathrm{Tl}$ & 0.15 & 0.00 & 0.14 & 0.31 & 0.22 & 0.00 & 0.00 & 0.00 & 0.21 & 0.36 & 0.00 & 0.19 & 0.00 & 0.23 \\
\hline $\mathrm{Zn}$ & 0.00 & 0.14 & 0.00 & 0.00 & 0.00 & 0.14 & 0.20 & 0.19 & 0.00 & 0.00 & 0.07 & 0.00 & 0.19 & 0.00 \\
\hline $\mathrm{Hg}$ & 30.33 & 29.94 & 29.85 & 29.76 & 28.74 & 28.70 & 28.59 & 28.12 & 24.70 & 27.69 & 27.31 & 23.97 & 23.61 & 23.15 \\
\hline $\mathrm{Cu}$ & 13.52 & 13.21 & 14.10 & 14.22 & 15.30 & 13.56 & 13.09 & 13.66 & 18.14 & 15.56 & 15.45 & 18.17 & 18.27 & 19.29 \\
\hline $\mathrm{Sb}$ & 18.94 & 18.48 & 19.13 & 18.94 & 18.98 & 18.22 & 17.88 & 18.15 & 19.56 & 18.90 & 19.52 & 19.66 & 19.23 & 19.77 \\
\hline As & 0.46 & 0.71 & 0.53 & 0.48 & 0.54 & 0.76 & 0.77 & 0.80 & 0.49 & 0.52 & 0.65 & 0.53 & 0.75 & 0.52 \\
\hline $\mathrm{Se}$ & 34.61 & 35.97 & 34.45 & 34.83 & 34.93 & 35.93 & 35.74 & 35.17 & 33.91 & 34.55 & 33.77 & 33.93 & 35.46 & 33.87 \\
\hline $\mathrm{S}$ & 1.39 & 1.28 & 1.57 & 1.51 & 1.80 & 1.26 & 1.15 & 1.21 & 2.39 & 1.83 & 2.18 & 2.33 & 1.81 & 2.57 \\
\hline Total & 100.67 & 101.07 & 101.07 & 101.38 & 102.00 & 99.93 & 98.84 & 98.73 & 100.93 & 100.68 & 100.40 & 100.37 & 100.87 & 100.97 \\
\hline $\mathrm{Cu}_{\text {тОт }}$ & 5.266 & 5.154 & 5.405 & 5.529 & 5.906 & 5.341 & 5.245 & 5.380 & 6.827 & 6.036 & 5.755 & 6.784 & 6.847 & 7.169 \\
\hline $\mathrm{Cu}$ & 3.009 & 2.855 & 3.031 & 3.194 & 3.421 & 2.921 & 2.873 & 2.890 & 3.772 & 3.439 & 2.978 & 3.619 & 3.651 & 3.894 \\
\hline $\mathrm{Ag}$ & 0.292 & 0.287 & 0.293 & 0.306 & 0.309 & 0.314 & 0.318 & 0.331 & 0.338 & 0.275 & 0.276 & 0.333 & 0.276 & 0.331 \\
\hline$\sum A$ & 3.301 & 3.142 & 3.325 & 3.500 & 3.731 & 3.235 & 3.191 & 3.221 & 4.110 & 3.714 & 3.254 & 3.953 & 3.927 & 4.225 \\
\hline $\mathrm{Cu}^{*}$ & 2.258 & 2.299 & 2.374 & 2.335 & 2.485 & 2.419 & 2.372 & 2.490 & 3.055 & 2.597 & 2.777 & 3.165 & 3.197 & 3.275 \\
\hline $\mathrm{Fe}$ & 0.000 & 0.000 & 0.000 & 0.000 & 0.060 & 0.000 & & & 0.000 & 0.030 & 0.000 & 0.028 & 0.035 & 0.024 \\
\hline $\mathrm{Cd}$ & 0.000 & 0.021 & 0.000 & 0.000 & 0.000 & 0.000 & 0.016 & 0.000 & 0.000 & 0.000 & 0.044 & 0.000 & 0.047 & 0.000 \\
\hline $\mathrm{Tl}$ & 0.018 & 0.000 & 0.017 & 0.037 & 0.027 & 0.000 & & 0.000 & 0.025 & 0.043 & 0.000 & 0.022 & 0.000 & 0.026 \\
\hline $\mathrm{Zn}$ & 0.000 & 0.053 & 0.000 & 0.000 & 0.000 & 0.053 & 0.077 & 0.074 & 0.000 & 0.000 & 0.024 & 0.000 & 0.068 & 0.000 \\
\hline $\mathrm{Hg}$ & 3.742 & 3.701 & 3.626 & 3.665 & 3.515 & 3.581 & 3.628 & 3.510 & 2.945 & 3.403 & 3.223 & 2.835 & 2.803 & 2.725 \\
\hline$\Sigma B+C$ & 6.018 & 6.074 & 6.017 & 6.037 & 6.087 & 6.053 & 6.093 & 6.075 & 6.025 & 6.073 & 6.068 & 6.049 & 6.150 & 6.050 \\
\hline $\mathrm{Sb}$ & 3.850 & 3.765 & 3.828 & 3.842 & 3.824 & 3.746 & 3.738 & 3.733 & 3.843 & 3.828 & 3.796 & 3.831 & 3.762 & 3.835 \\
\hline As & 0.150 & 0.235 & 0.172 & 0.158 & 0.176 & 0.254 & 0.262 & 0.267 & 0.157 & 0.172 & 0.204 & 0.169 & 0.238 & 0.165 \\
\hline$\Sigma D$ & 4.000 & 4.000 & 4.000 & 4.000 & 4.000 & 4.000 & 4.000 & 4.000 & 4.000 & 4.000 & 4.000 & 4.000 & 4.000 & 4.000 \\
\hline $\mathrm{Se}$ & 10.849 & 11.296 & 10.631 & 10.898 & 10.854 & 11.389 & 11.523 & 11.152 & 10.272 & 10.786 & 10.125 & 10.193 & 10.696 & 10.131 \\
\hline $\mathrm{S}$ & 1.069 & 0.992 & 1.191 & 1.160 & 1.374 & 0.985 & 0.913 & 0.948 & 1.784 & 1.409 & 1.610 & 1.726 & 1.343 & 1.895 \\
\hline$\Sigma Y+Z$ & 11.918 & 12.289 & 11.823 & 12.058 & 12.229 & 12.374 & 12.436 & 12.100 & 12.057 & 12.195 & 11.736 & 11.919 & 12.039 & 12.026 \\
\hline
\end{tabular}

The number of atoms is normalized to $(\mathrm{Sb}+\mathrm{As})=4 \mathrm{apfu} .{ }^{*} \mathrm{Cu}$ calculated as $\mathrm{Cu}_{\text {tot }}-(10-\mathrm{Ag})$ 
Fig. 3 Graph $\mathrm{Cu}+\mathrm{Ag}($ apfu) vs. $\mathrm{Hg}$ (apfu) for pošepnýite.

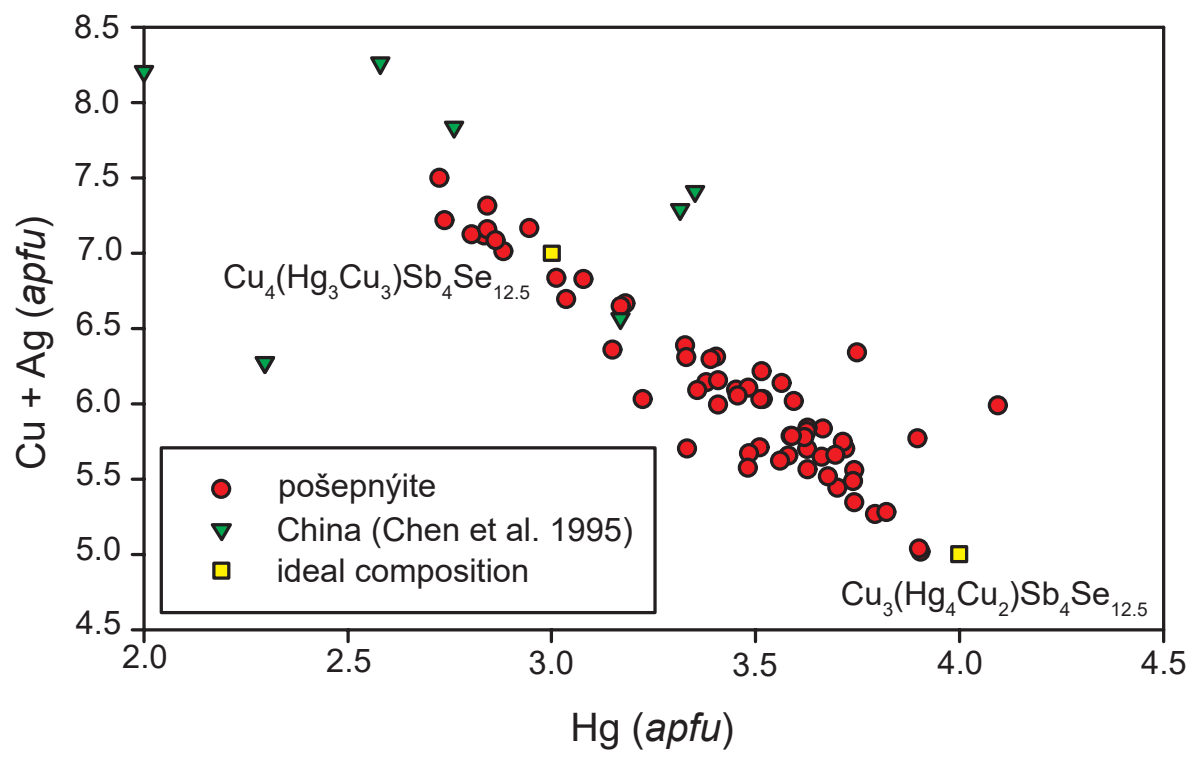

The general structural formula of the tetrahedrite group minerals can be best defined as ${ }^{M(2)} A_{6}{ }^{M(1)}\left(B_{4} C_{2}\right)^{X(3)}$ $D_{4}^{\mathrm{S}(1)} Y_{12}{ }^{\mathrm{S}(2)} Z$ (Biagioni et al. 2020a). Pošepnýite is the first member of the tetrahedrite group with the content of divalent metal $(\mathrm{Hg})$ significantly higher than 2 apfu. The Hg contents were found in the range 2.73-4.10 apfu (Fig. 3) and total contents of divalent metals in the range 2.75-4.23 apfu, respectively (Fig. 4). The observed low contents of $\mathrm{Cu}(+\mathrm{Ag})$ 5.02-7.50 apfu indicate the presence of vacancies in the triangular $A$ position in the range 1.73-3.06 pfu (Fig. 5), which was also confirmed by the results of our single-crystal study (see below). The presence of vacancies also enables the charge balancing of the pošepnýite formula. Published structural studies confirmed the possibility of the presence of vacancies in the triangular $A$ site due to the heterovalent substitution $\mathrm{Te}^{4+}-\mathrm{Sb}^{3+}$ in goldfieldite (Moëlo et al. 2008).

Concerning the anions, the minor contents of $\mathrm{S}$ (0.67-2.02 apfu) correlate negatively with $\mathrm{Hg}$ contents (Fig. 6), but the determined range of $\mathrm{SSe}_{-1}$ substitution in pošepnýite is distinctly more limited than in the coexisting Hg-hakite (up to 4.03 apfu S, Škácha et al. 2017b). The observed total occupation of $(Y+Z)$ positions $12.12(\mathrm{Se}+\mathrm{S})$ apfu (range 11.28-12.75) is below, but close to, the ideal value of 12.5 apfu (Fig. 7) which is required by charge balance and confirmed by our study of the

Fig. 4 Graph $\mathrm{Cu}+\mathrm{Ag}(a p f u) v s$. $\mathrm{Hg}+\mathrm{Fe}$ $+\mathrm{Zn}+\mathrm{Cd}(a p f u)$ for pošepnýite. crystal structure. A small deficit against the ideal value can be explained by analytical uncertainty, also seen in many published tetrahedrite analyses (Repstock et al. 2016; Wang et al. 2018).

Vacancies are not very common in minerals of the tetrahedrite group but have been confirmed through structural studies (e.g., Maske and Skinner 1971; Makovicky and Skinner 1979; Rozhdestvenskaya et al. 1993; Makovicky et al. 2005; Welch et al. 2018). The chemical variability encompasses anions too, with the substitution of $\mathrm{S}$ by $\mathrm{Se}$, or with the occurrence of vacancies (Biagioni et al. 2020a).

The results of the chemical study of pošepnýite, as well as the crystal structure study, indicate that it is a solid solution which can be expressed by the ideal formula $\left(\mathrm{Cu}_{3+x} \square_{3-x}\right)_{\Sigma 6}\left(\mathrm{Hg}_{4-x} \mathrm{Cu}_{2+x}\right)_{\Sigma 6} \mathrm{Sb}_{4}\left(\mathrm{Se}_{12.5} \square_{0.5}\right)_{\Sigma 13}$ with $x$ restricted to the range $0 \leq x<<2$; results of the

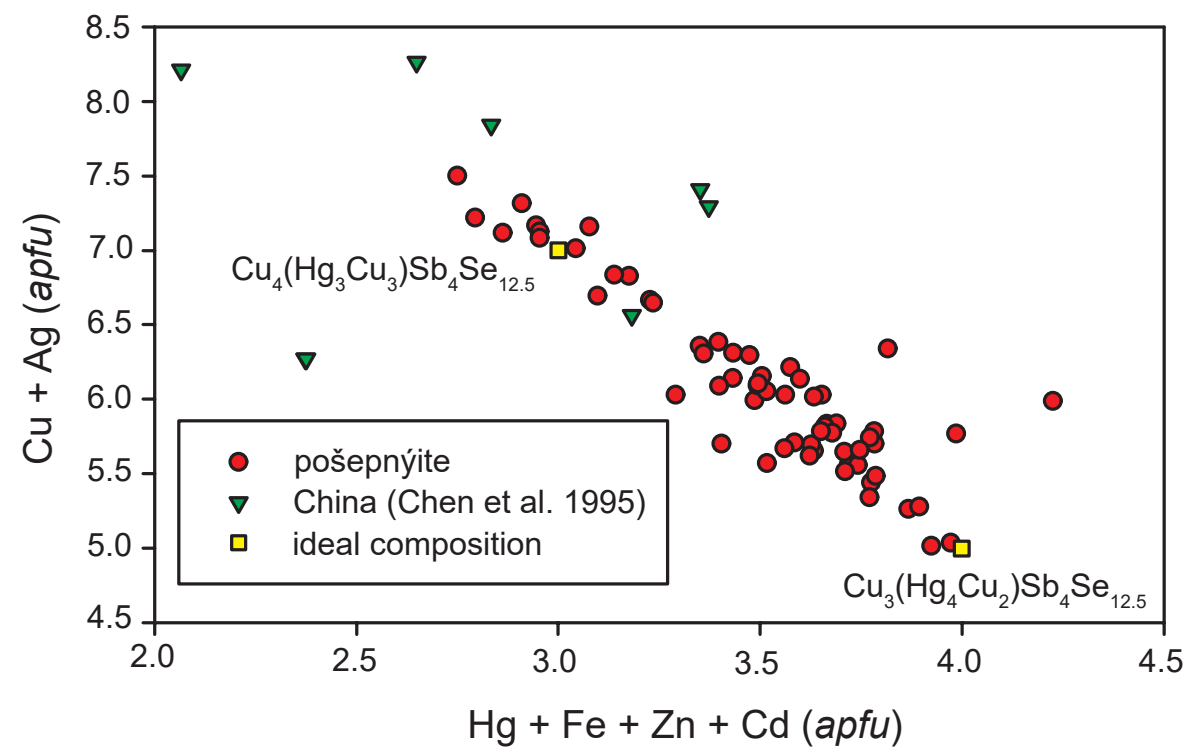




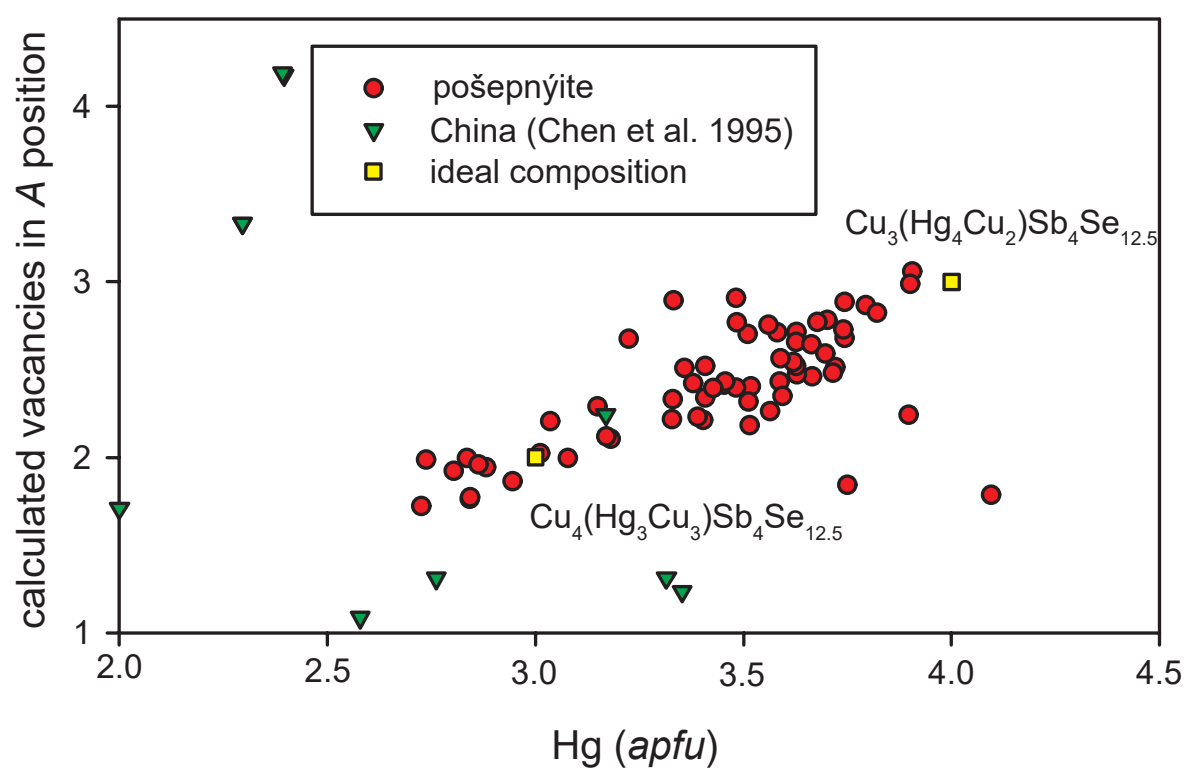

Fig. 5 Graph $\mathrm{Hg}(a p f u) v s$. calculated content of vacancies in $A$ position ( $p f u$ ) for pošepnýite. chemical study indicate a range from -0.09 to 1.27 . The empirical formula of pošepnýite, based on an average of 62 electron-microprobe analyses, is $\left(\mathrm{Cu}_{3.33} \mathrm{Ag}_{0.28}\right)_{\Sigma 3.61}$ $\left(\mathrm{Hg}_{3.43} \mathrm{Cu}_{2.50} \mathrm{Zn}_{0.03} \mathrm{Cd}_{0.03} \mathrm{Fe}_{0.01}\right)_{\Sigma 6.00}\left(\mathrm{Sb}_{3.88} \mathrm{As}_{0.12}\right)_{\Sigma 4.00}$ $\left(\mathrm{Se}_{10.83} \mathrm{~S}_{1.29}\right)_{\Sigma 12.12}$. The ideal formula is $\left(\mathrm{Cu}_{3+x}^{+} \square_{3-x}\right)_{\Sigma 6}\left(\mathrm{Hg}^{2+}{ }_{4-x}\right.$ $\left.\mathrm{Cu}^{+}{ }_{2+x}\right)_{\Sigma 6} \mathrm{Sb}_{4}\left(\mathrm{Se}_{12.5} \square_{0.5}\right)_{\Sigma 13}, 0 \leq x<<2$, which requires $\mathrm{Cu}$ 12.25, $\mathrm{Hg} 30.93$, Sb 18.77 and Se 38.05, total 100.00 wt. \% (for $x=0$ ) or $\mathrm{Cu} 17.65$, $\mathrm{Hg} 23.87, \mathrm{Sb} 19.32$, Se 39.16 , total 100.00 wt. $\%$ (for $x=1$ ).

\section{Crystal structure study}

The first investigations, which determined relation of the crystal structure of pošepnýite to other minerals of the tetrahedrite group, were carried out by the electron

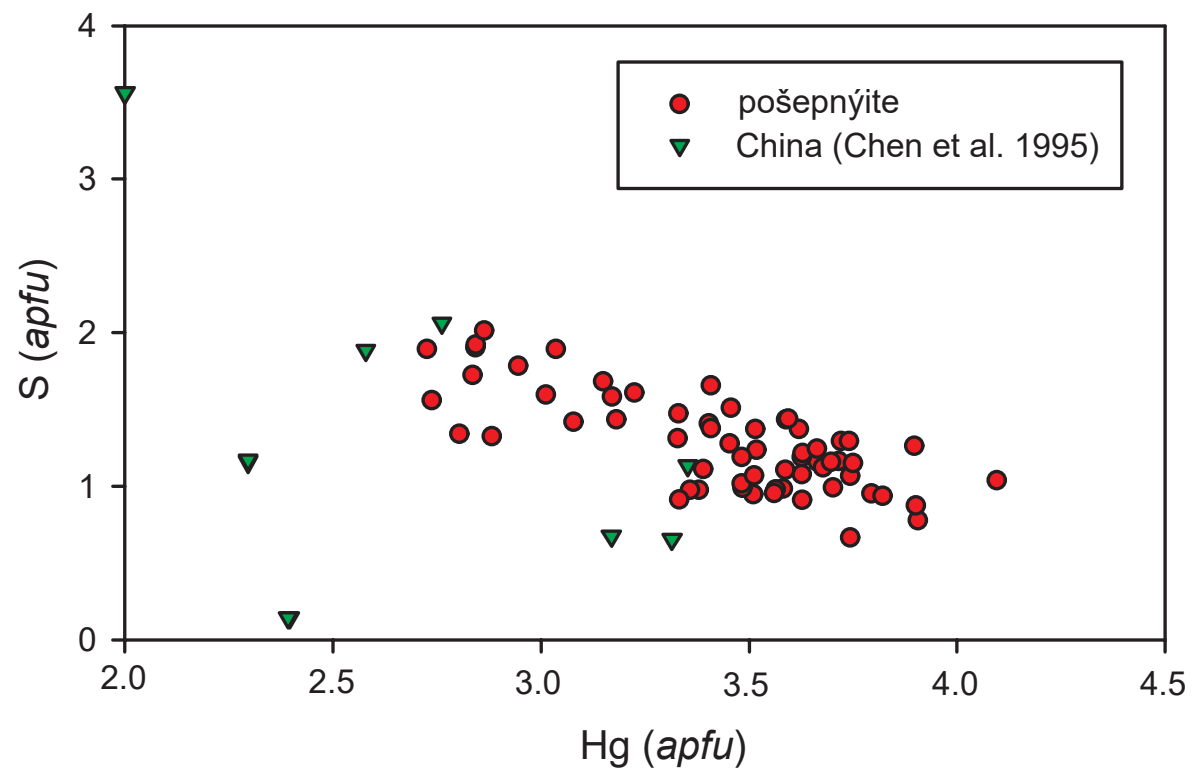

back-scatter diffraction (EBSD) method (Škácha et al. 2017b). A zoned aggregate of this mineral overgrown by hakite-( $\mathrm{Hg}$ ) and tetrahedrite-( $\mathrm{Zn})$ (Fig. 1) was selected for the EBSD study. The fit of all three sets of EBSD data from the studied aggregate not only supports them having the tetrahedrite type of structure, but also the identical crystallographic orientation of all three phases (Škácha et al. 2017b). Close relations between the crystal structure of pošepnýite and hakite- $(\mathrm{Hg})$ were also confirmed by the results of Raman spectroscopy (Škácha et al. 2017b).

The fragment for single-crystal diffraction study was hand-picked from a polished section of an aggregate preanalyzed utilizing electron microprobe (Fig. 8); this aggregate was free of other members of tetrahedrite group. Dimensions of the investigated fragment were 0.022 $0.012 \mathrm{~mm}$, approximating when corrected for absorption to a sphere with a diameter equal to $0.02 \mathrm{~mm}$. The absorption coefficient $\mu$ is $43.90 \mathrm{~mm}^{-1}$. Diffraction data were obtained on a Rigaku SuperNova singlecrystal diffractometer equipped with Atlas S2 CCD detector and microfocus X-ray tube using MoKa radiation. Other details about the data-collection are given in Tab. 4. Crystal structure determination is based on 334 independent reflections, with 270 of them above the threshold $I>3 \sigma(I)$. Refinement (on $F^{2}$, with anisotropic displacement parameters) was concluded at

Fig. 6 Graph $\mathrm{Hg}(a p f u) v s . \mathrm{S}(\mathrm{a} f u)$ for pošepnýite. 
Fig. 7 Graph Se (apfu) vs. S (apfu) for pošepnýite; solid line represents $\mathrm{Se}+\mathrm{S}$ $=12.5 ;$ dashed line $\mathrm{Se}+\mathrm{S}=13$.

the $R$-value of 0.0510 (wR 0.1083$)$ for the above selected reflections, i.e., at $R$ equal to 0.0681 ( $w R 0.1141$ ) for all reflections, 18 refined parameters and 6 constraints. Refined atom coordinates and anisotropic displacement parameters for pošepnýite are given in Tabs 5 and 6, and selected interatomic distances are given in Tab. 7 . The following unit-cell data for space group $I-43 m$ were obtained: $a$ 10.9636(11) $\AA$, and $V$ 1317.8(2) $\AA^{3}$ (Tab. 4). The paucity of pošepnýite did not allow us to collect powder X-ray diffraction data. Therefore, calculated powder diffraction data are given in Tab. 8. The CIF file, also containing a block with the reflections, is deposited at the Journal's webpage $w w w$.jgeosci.org.

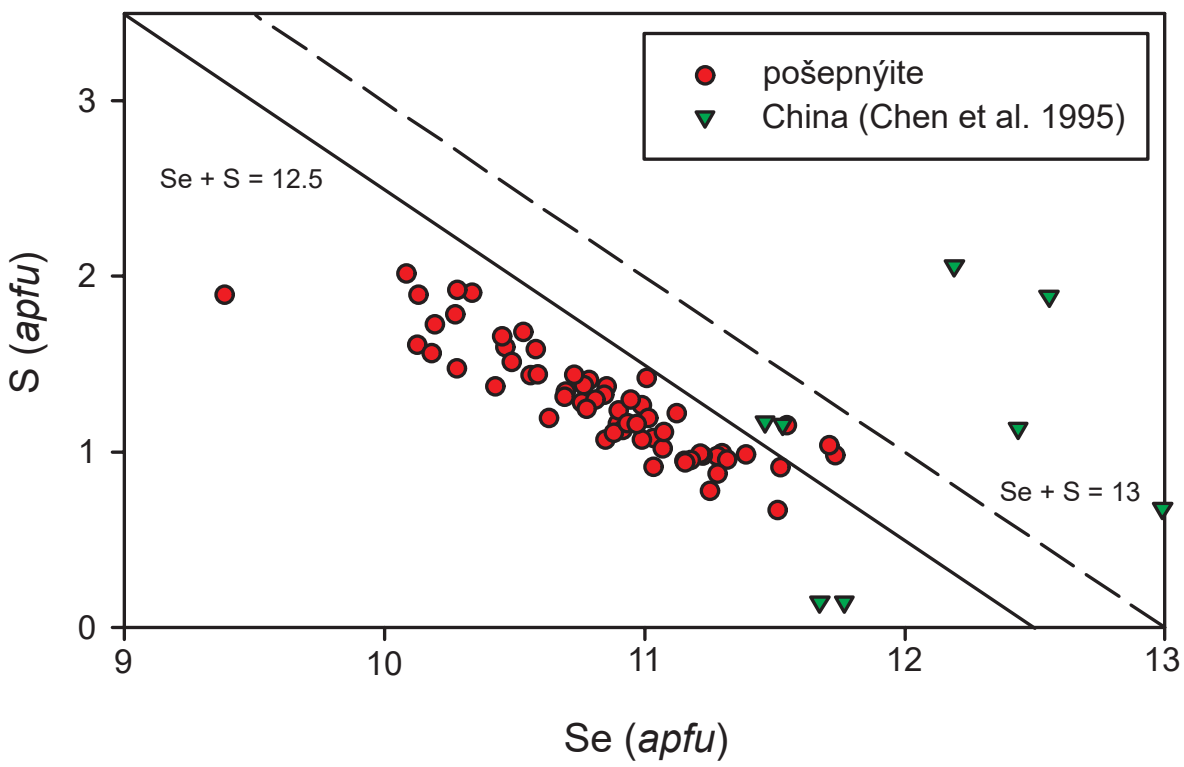

cation site $M 2$ (Tab. 5-7). The main anion site Se1 participates in all of these cation coordination polyhedra, and there is a minority anion ' $\mathrm{Se} 2$ ' tying the six coordination triangles of $\mathrm{Cu} 2$ in the cavity of the tetrahedral framework into one cluster. In tetrahedrite, the triangular sites are $M^{+}(\mathrm{Cu}$ and $\mathrm{Ag}), \mathrm{Sb}$ (and As) are $M^{3+}$, which dictates the valence of the tetrahedrally coordinated site to be a mixed one, $2 / 3 M^{+}$(4 atoms) and 1/3 $M^{2+}$ (2 atoms). This is preferably achieved by partial substitution of tetrahedrally coordinated $\mathrm{Cu}$ by a divalent metal, and $\mathrm{Fe}, \mathrm{Zn}$, and $\mathrm{Hg}$ are the preferred cations. Formal $\mathrm{Cu}^{2+}$ is avoided whenever they are available. Thus, ideal hakite(Hg) is $\mathrm{Cu}_{6} \mathrm{Cu}_{4} \mathrm{Hg}_{2} \mathrm{Sb}_{4} \mathrm{Se}_{13}$ (e.g., Škácha et al. 2016). It is

\section{Description of crystal structure}

As in the crystal structure of (ideal) tetrahedrite, the cubic structure of pošepnýite is a tetrahedral framework with cavities and a part of the tetrahedra replaced by $\mathrm{SbSe}_{3}$ coordination pyramids (Fig. 9). It has one type of pyramidal $\mathrm{Sb}$ position, one type of tetrahedrally coordinated cation position $M 1$ occupied by $(\mathrm{Hg}, \mathrm{Cu})$, and one type of partly vacant triangular

Fig. 8 BSE photo of pošepnýite (P) used for the SXRD (left grain). The association is represented by antimonselite (A), př́bramite (Pr) and tiemannite (tiny white grains).

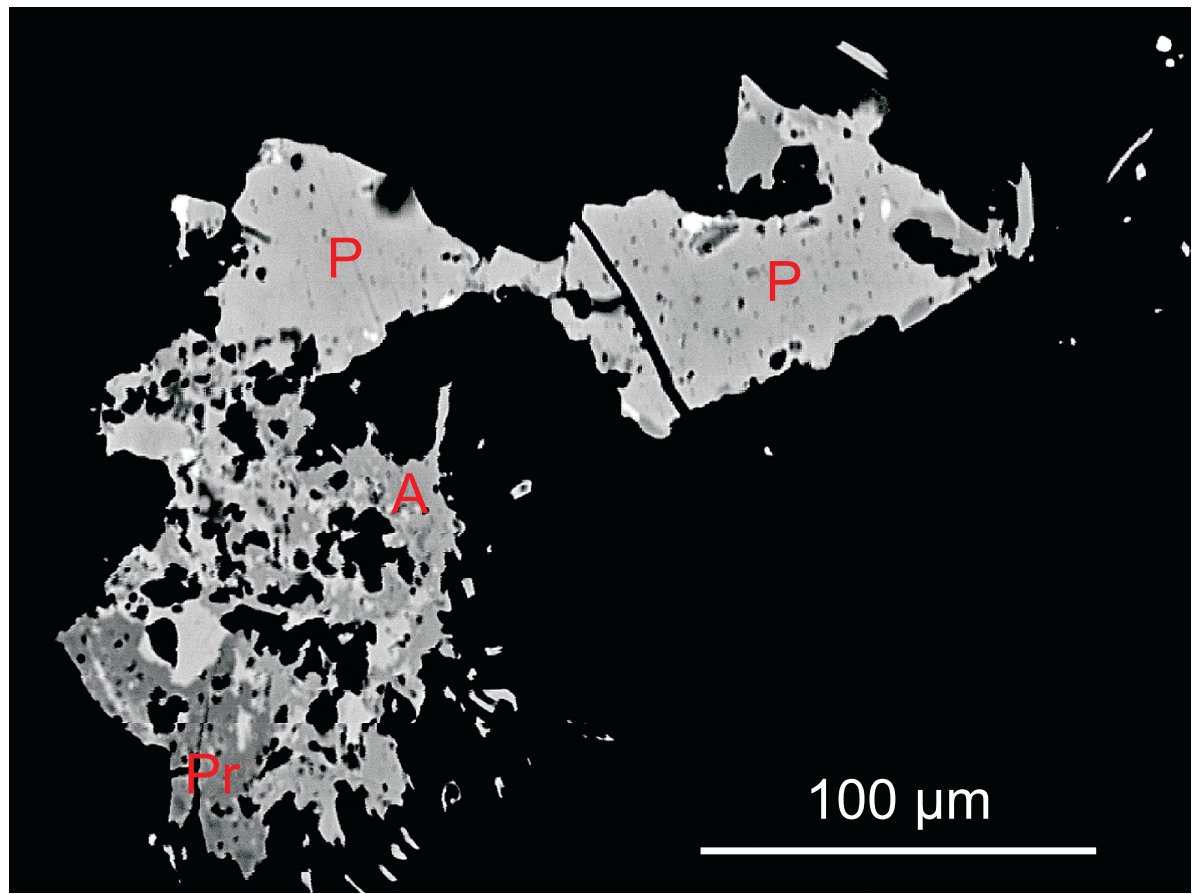


Tab. 4 Summary of data collection conditions and refinement parameters for pošepnýite

\begin{tabular}{ll}
\hline Structural formula & $\mathrm{Cu}_{6.678} \mathrm{Hg}_{2.922} \mathrm{Ag}_{0.420} \mathrm{Sb}_{4} \mathrm{Se}_{12.576}$ \\
$a[\AA]$ & $10.9636(11)$ \\
$V\left[\AA^{3}\right]$ & $1317.8(2)$ \\
$Z$ & 2 \\
Space group & $I-43 m$ \\
$D_{\text {calc }}\left(\mathrm{g} \mathrm{cm}^{-3}\right)$ & 6.391 \\
Temperature & $296 \mathrm{~K}$ \\
Wavelength & $\mathrm{MoK \alpha}, 0.71073 \AA$ \\
Crystal dimensions & $0.022 \times 0.020 \times 0.012 \mathrm{~mm}^{3}$ \\
Collection mode & $\omega \mathrm{scans}$ to fill an Ewald sphere \\
Limiting $\theta$ angles & $3.72-28.45^{\circ}$ \\
Limiting Miller indices & $-14 \leq h \leq 14,-14 \leq k \leq 14,-13 \leq l \leq 14$ \\
No. of reflections & 4277 \\
No. of unique reflections & 334 \\
No. of observed reflections (criterion) & $270[I>3 \sigma(I)]$ \\
Absorption correction (mm $\left.{ }^{-1}\right)$, method & 43.90, Sphere \\
$T_{\text {min }} / T_{\text {max }}$ & $0.271 / 0.453$ \\
$R_{\text {int }}$ & 0.122 \\
$F_{\text {ooo }}$ & 2158 \\
Parameters, constraints, restraints & $18,6,0$ \\
$R, w R$ (obs) & $0.0510,0.1083$ \\
$R, w R$ (all) & $0.0681,0.1141$ \\
GOF (obs, all) & $1.82,1.71$ \\
Weighting scheme, weights & $\sigma, 1 /\left(\sigma^{2}(F)+0.0004 F^{2}\right)$ \\
$\Delta \rho_{\text {min }}, \Delta \rho_{\text {max }}\left(\mathrm{e} \AA \AA^{-3}\right)$ & $-2.29,2.22(0.90 \AA$ to Se 2$)$ \\
\hline
\end{tabular}

Tab. 5 Atom coordinates, isotropic and equivalent displacement parameters and occupation factors for the structure of pošepnýite

\begin{tabular}{llllll}
\hline & \multicolumn{1}{c}{$x / a$} & \multicolumn{1}{c}{$y / b$} & \multicolumn{1}{c}{$z / c$} & \multicolumn{1}{c}{$U_{\text {eq }}$} & Occ. $(<1)$ \\
\hline $\mathrm{Hg} 1 / \mathrm{Cu} 1$ & 0.25 & 0.5 & 0 & $0.0368(7)$ & $0.487 / 0.513$ \\
$\mathrm{Sb} 2$ & $0.23497(15)$ & $0.76503(15)$ & $0.23497(15)$ & $0.0239(4)$ & \\
$\mathrm{Se} 1$ & $0.3876(2)$ & $0.6124(2)$ & $0.1476(2)$ & $0.0356(8)$ & \\
$\mathrm{Cu} 2 / \mathrm{Ag} 2$ & 0.5 & 0.5 & $0.2959(5)$ & $0.0502(18)$ & $0.6 / 0.07$ \\
$\mathrm{Se} 2 / \square$ & 0.5 & 0.5 & 0.5 & $0.059(3)$ & $0.576 / 0.424$ \\
\hline
\end{tabular}

Tab. 6 Anisotropic displacement parameters for the structure of pošepnýite

\begin{tabular}{llllllll}
\hline & \multicolumn{1}{c}{$U^{11}$} & \multicolumn{1}{c}{$U^{22}$} & \multicolumn{1}{c}{$U^{33}$} & \multicolumn{1}{c}{$U^{12}$} & \multicolumn{1}{c}{$U^{13}$} & \multicolumn{1}{c}{$U^{23}$} \\
\hline $\mathrm{Hg} 1 / \mathrm{Cu} 1$ & $0.0499(17)$ & $0.0302(8)$ & $0.0302(8)$ & 0 & 0 & 0 \\
$\mathrm{Sb} 2$ & $0.0239(7)$ & $0.0239(7)$ & $0.0239(7)$ & $0.0016(8)$ & $-0.0016(8)$ & $0.0016(8)$ \\
$\mathrm{Se} 1$ & $0.0343(10)$ & $0.0343(10)$ & $0.0382(18)$ & $0.0050(15)$ & $0.0066(10)$ & $-0.0066(10)$ \\
$\mathrm{Cu} 2 / \mathrm{Ag} 2$ & $0.073(3)$ & $0.073(3)$ & $0.005(3)$ & $-0.010(6)$ & 0 & 0 & \\
$\mathrm{Se} 2$ & $0.073(3)$ & $0.073(3)$ & $0.005(3)$ & $-0.010(6)$ & 0 & 0 & \\
\hline
\end{tabular}

the principal remaining divalent elements being $\mathrm{Zn}$ and $\mathrm{Cd}$.

In respect to the ideal tetrahedrite model, pošepnýite is a variant with a defect tetrahedrite-like structure so that the structural constraints present in tetrahedrite are not valid for pošepnýite. Our structural refinement indicates a substantial amount of cation vacancies in the triangular cation $M 2$ site of pošepnýite. Thus, the tetrahedral cation site was refined as $\mathrm{Cu}$ and $\mathrm{Hg}$ in mutual substitution, and with full resulting occupancy, the latter needed for the preservation of structural stability. The $\mathrm{Sb}$ site is fully occupied as well, and the small amount of Ag indicated by chemical analysis was ascribed to the copperoccupied triangular M2 sites, in agreement with the results of numerous studies of the tetrahedrite-tennantite group (e.g., Riley 1974; Sack and Loucks 1985; Lynch 1989; Biagioni et al. 2020a). These assignments avoid any problems of Sel anions without sufficient cation neighbors, which would lead to a structure collapse. The tetrahedral $\mathrm{Hg} 1$ and $\mathrm{Cu} 1$ cations are in the same special position (Tab. 5). Their initial atomic proportions were approximated using the refined typical bond-length to the tetrahedral ligands. This was followed by a free refinement, constrained to a combined full occupancy of the site. $\mathrm{Cu} 2$ and Ag2 in the triangular sites were refined with the same geo-

interesting to compare the $a$ value of pošepnýite with that of hakite-(Hg) from the same locality, equal to $10.878 \AA$ (Škácha et al. 2016). This hakite-(Hg) has 1.61 apfu $\mathrm{Hg}$,

Tab. 7 Selected interatomic distances (in $\AA$ ) in the structure of pošepnýite

\begin{tabular}{ll}
\hline $\mathrm{Hg} 1 / \mathrm{Cu} 1-\mathrm{Se} 1$ & $2.532(2)(4 \times)$ \\
$\mathrm{Sb} 2-\mathrm{Se} 1$ & $2.553(2)(3 \times)$ \\
$\mathrm{Cu} 2 / \mathrm{Ag} 2-\mathrm{Se} 1$ & $2.238(6)$ \\
$\mathrm{Cu} 2 / \mathrm{Ag} 2-\mathrm{Se} 2$ & $2.238(6)(4 \times)$ \\
\hline
\end{tabular}

metric coordinates, with the ratio given by the chemical analysis because the total occupancy of the $M 2$ site was a refined parameter. Anisotropic displacement parameters $(A D P S)$ were refined as common for the two cations in each of these two sets.

The problem outstanding in the chemical analyses is the occupancy of the $\mathrm{Se} 2$ site. The $\mathrm{Cu} 2 / \mathrm{Ag} 2-\mathrm{Se} 2$ distance suggests that the $\mathrm{Se} 2$ site can either be a mixed $(\mathrm{Se}, \mathrm{S})$ site, or there is some vacancy. A more plausible explanation seems to be that the vacancy is present at the 
Tab. 8 Calculated powder X-ray diffraction data for pošepnýite

\begin{tabular}{|c|c|c|c|c|}
\hline$I_{\text {calc. }}$ & $d_{\text {calc. }}$ & $h$ & $k$ & $l$ \\
\hline 8.6 & 7.7524 & 1 & 1 & 0 \\
\hline 1.4 & 5.4818 & 2 & 0 & 0 \\
\hline 10.6 & 4.4759 & 2 & 1 & 1 \\
\hline 6.6 & 3.8762 & 2 & 2 & 0 \\
\hline 100.0 & 3.1649 & 2 & 2 & 2 \\
\hline 24.1 & 2.9301 & 3 & 2 & 1 \\
\hline 5.3 & 2.7409 & 4 & 0 & 0 \\
\hline 5.2 & 2.5841 & 3 & 3 & 0 \\
\hline 9.2 & 2.5841 & 4 & 1 & 1 \\
\hline 1.2 & 2.4515 & 4 & 2 & 0 \\
\hline 2.1 & 2.2379 & 4 & 2 & 2 \\
\hline 12.0 & 2.1501 & 4 & 3 & 1 \\
\hline 16.2 & 2.0017 & 5 & 2 & 1 \\
\hline 65.4 & 1.9381 & 4 & 4 & $\mathbf{0}$ \\
\hline 1.9 & 1.8802 & 5 & 3 & 0 \\
\hline 3.4 & 1.8802 & 4 & 3 & 3 \\
\hline 2.8 & 1.7785 & 5 & 3 & 2 \\
\hline 13.3 & 1.7785 & 6 & 1 & 1 \\
\hline 2.4 & 1.7335 & 6 & 2 & 0 \\
\hline 31.3 & 1.6528 & 6 & 2 & 2 \\
\hline 1.3 & 1.5825 & 4 & 4 & 4 \\
\hline 1.1 & 1.5505 & 5 & 5 & 0 \\
\hline 2.1 & 1.5505 & 7 & 1 & 0 \\
\hline 2.8 & 1.5505 & 5 & 4 & 3 \\
\hline 2.5 & 1.4920 & 6 & 3 & 3 \\
\hline 7.9 & 1.3705 & 8 & 0 & 0 \\
\hline 1.8 & 1.3495 & 7 & 4 & 1 \\
\hline 9.2 & 1.3104 & 6 & 5 & 3 \\
\hline 1.9 & 1.2745 & 7 & 4 & 3 \\
\hline 6.5 & 1.2745 & 8 & 3 & 1 \\
\hline 10.5 & 1.2576 & 6 & 6 & 2 \\
\hline 3.3 & 1.2414 & 7 & 5 & 2 \\
\hline 1.8 & 1.2258 & 8 & 4 & 0 \\
\hline 1.6 & 1.2107 & 8 & 3 & 3 \\
\hline 2.8 & 1.1822 & 6 & 5 & 5 \\
\hline 3.1 & 1.1822 & 7 & 6 & 1 \\
\hline 2.5 & 1.1557 & 7 & 5 & 4 \\
\hline 3.4 & 1.1557 & 8 & 5 & 1 \\
\hline 1.2 & 1.1308 & 7 & 6 & 3 \\
\hline 2.4 & 1.1308 & 9 & 3 & 2 \\
\hline 12.4 & 1.1190 & 8 & 4 & 4 \\
\hline 1.6 & 1.1075 & 8 & 5 & 3 \\
\hline
\end{tabular}

Only calculated lines with $I \geq 1$ are shown.

$\mathrm{Se} 2$ site rather than at the $\mathrm{Se} 1$ site, taking into account the significant displacement parameter of $\mathrm{Cu} 2 / \mathrm{Ag} 2$ site atoms coordinated by "empty" Se2 (having large $U_{\text {eq }}$ itself). While considering a vacancy present at the $\mathrm{Se} 2$ site (Se2 occupancy $\sim 60 \%$ ), the $U_{\text {eq }}$ value slightly decreases to $0.06 \AA^{2}$ (from about $0.09 \AA^{2}$ ). This agrees with the coordination point of view because four $(\mathrm{Cu}, \mathrm{Ag}) 2$ atoms can hardly be expected to maintain their $M 2$ positions with a central Se2 anchoring them only in about $50 \%$ of cases. The $U_{\text {eq }}$ value refined for Cu2 looks very plausible, typical for a tetrahedrite-like structure. Structure refinement cannot further improve this situation because of correlations between occupancy, ADP, and an unknown $\mathrm{Se} / \mathrm{S}$ ratio in the $\mathrm{Se} 2$ site.

The refined $(\mathrm{Cu}, \mathrm{Hg}) 1-\mathrm{Se} 1$ distance is $2.532 \AA$, whereas the four $\mathrm{SbSe}_{3}$ pyramids facing into the framework cavity have the $\mathrm{Sb}-\mathrm{Se} 1$ bond length equal to $2.553 \AA$. This creates quite a regular structure framework. The distance $\mathrm{Sb}-\mathrm{Se} 2$, in the direction of the lone electron pair of Sb2 is equal to $4.463 \AA$, whereas those to six Se1 atoms on the surface of the cavity fan out in a flat manner, all equal to $4.239 \AA$.

The $U$ value refined for $\mathrm{Cu} 2$ looks very plausible, typical for a tetrahedrite-like structure. When their highly anisotropic displacement ellipsoid is not counted, the $(\mathrm{Cu}, \mathrm{Ag}) 2$ atoms are at $2.383 \AA$ from the two $\mathrm{Se} 1$ atoms and at $2.239 \AA$ from the average position of the $(\mathrm{Se}, \mathrm{S}) 2$ atom. Without ADPs, the three 'static' $\mathrm{Sb}-(\mathrm{Cu}, \mathrm{Ag}) 2$ distances from each $\mathrm{Sb}$ atom are $3.661 \AA$ (the angle between them is $51.24^{\circ}$ ), the adjacent $\mathrm{Cu} 2$ positions across the cavity are $3.167 \AA$ apart. With the ADPs taken into account, the $(\mathrm{Cu}, \mathrm{Ag}) 2$ positions in two adjacent wings of the 'propeller' are $3.12 \AA$ apart. The split of one Cu2 site, expressing its elevated ADP value perpendicular to its coordination triangle, is $0.08 \AA$. It might be mentioned that the preferred $\mathrm{Cu}-\mathrm{Cu}$ distances in copper-rich sulfosalts are shorter, of the order of $2.7 \AA$ (Makovicky 2006).

The $(\mathrm{Hg}, \mathrm{Cu}) \mathrm{Se}_{4}$ tetrahedra are not regular, the $\mathrm{Se}-$ $\mathrm{Hg}-\mathrm{Se}$ angle being $110.80^{\circ}$. The same is true for the coordination triangle of $\mathrm{Cu} 2$, the $\mathrm{Se} 1-\mathrm{Cu} 2-\mathrm{Se} 1$ angle being $93.97^{\circ}$ and the $\mathrm{Se} 1-\mathrm{Cu} 2-\mathrm{Se} 2$ angle $133.01^{\circ}$. The angle comprised of two strong short $\mathrm{Sb}-\mathrm{S}$ bonds is $93.66^{\circ}$. All these values are typical for the tetrahedrite-type structures (Foit and Hughes 2004; Karanović et al. 2003, and references therein).

The chemical formula, $\mathrm{Cu}_{6.678} \mathrm{Hg}_{2.922} \mathrm{Ag}_{0.420} \mathrm{Sb}_{4} \mathrm{Se}_{12.576}$ was obtained from the results of the structure refinement. It indicates that the structurally investigated fragment is close to the copper-rich, low-vacancy limit of the solid solution $\mathrm{Cu}_{3+x}\left(\mathrm{Hg}_{4-x} \mathrm{Cu}_{2+x}\right)_{\Sigma 6} \mathrm{Sb}_{4} \mathrm{Se}_{12.5}$.

\section{Relationship to known species}

Pošepnýite is a new member of the tetrahedrite group with dominant divalent $\mathrm{Hg}$ in the tetrahedral $M(1)$ site and a significant content of vacancies in the triangular $M(2)$ site. Its chemical composition can be expressed by the ideal formula $\left(\mathrm{Cu}^{+}{ }_{3+x} \square_{3-x}\right)_{\Sigma 6}\left(\mathrm{Hg}^{2+}{ }_{4-x} \mathrm{Cu}_{2+x}^{+}\right)_{\Sigma 6} \mathrm{Sb}_{4}\left(\mathrm{Se}_{12.5} \square_{0.5}\right)$ ${ }_{\Sigma 13}$, with the $x$ value restricted to the range $0 \leq x<<2$; results of chemical studies indicate a range from -0.09 to 1.27. A comparison of crystallographic parameters and physical properties of pošepnýite and similar phases is shown in Tab. 9. The general structural formula of 
a)

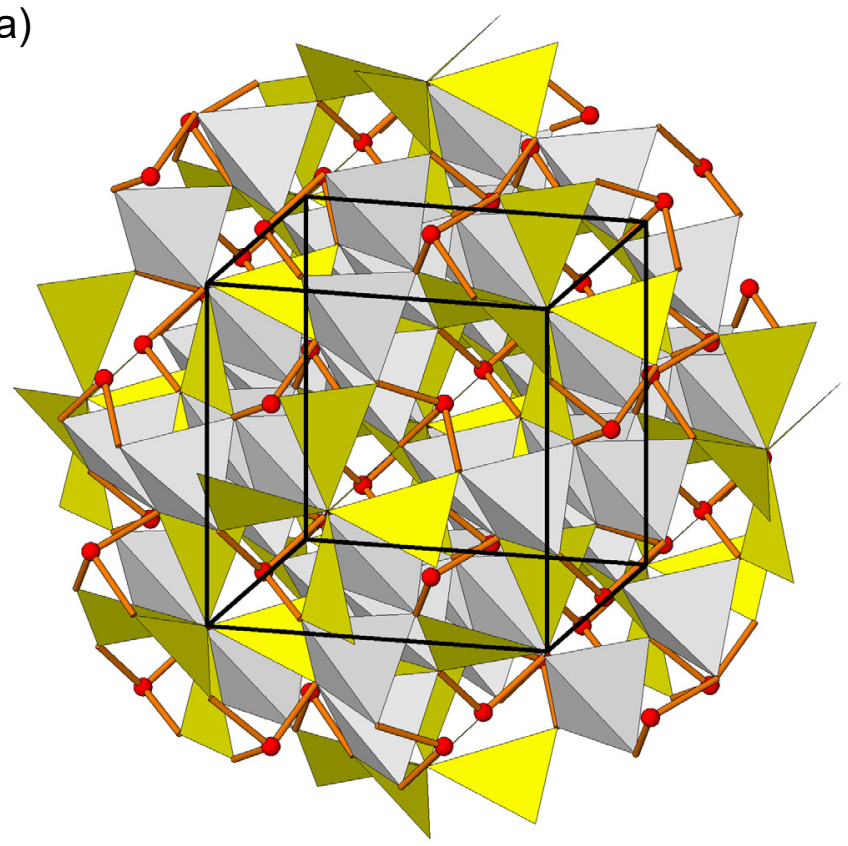

b)

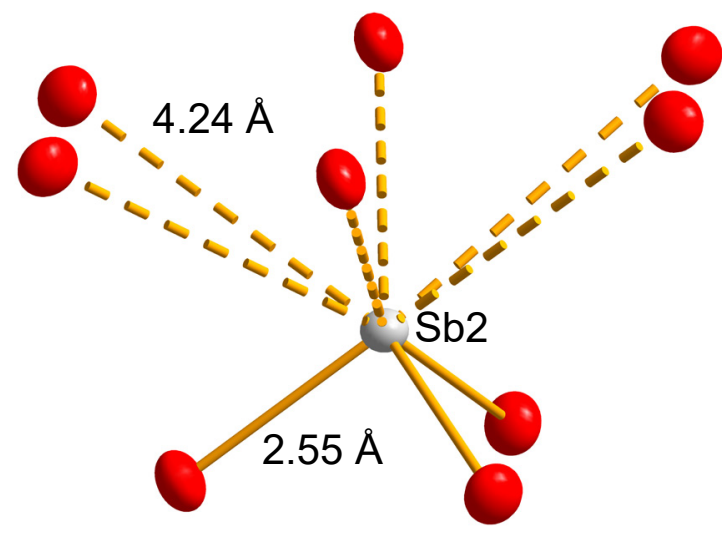

Fig. 9 Crystal structure of pošepnýite. a - a polyhedral representation of the structure viewed in general projection. (Cu1/Hg1)Se1 tetrahedra are grey, ((Cu2/Ag2)Se(1,2) triangles are yellow, $\mathrm{Sb}$ atoms are red; unit-cell edges are outlined in black solid-lines. $\mathbf{b}$ - Coordination environment of the $\mathrm{Sb} 2$ atom (silver grey) involving three short $\mathrm{Sb}-\mathrm{Se}$ bonds and six long $\mathrm{Sb}-\mathrm{Se}$ bonds due to active electron lone-pair on $\mathrm{Sb}^{3+}$.

the tetrahedrite group minerals has been formulated as ${ }^{M(2)} A_{6}{ }^{M(1)}\left(B_{4} C_{2}\right)^{X(3)} D_{4}^{\mathrm{S}(1)} Y_{12}{ }^{\mathrm{S}(2)} Z$ (Biagioni et al. 2020a). Pošepnýite, however, has a unique $B: C$ ratio, reaching ${ }^{M(1)}\left(B_{2} C_{4}\right)$ at the $\mathrm{Cu}$-poor end of the solid-solution. It is distinct from that of the general formula, and is different from the ratio displayed by the sensu-stricto members of the tetrahedrite group. In the recent classification of the members of the tetrahedrite group (Biagioni et al. 2020a), pošepnýite will be classified as an unassigned member, similar to the position of goldfieldite.

Pošepnýite is identical with an unnamed $\mathrm{Hg}-\mathrm{Cu}-\mathrm{Sb}$ selenide from Př́ibram (Škácha et al. 2017b) and probably also with an unnamed mineral phase $(\mathrm{Cu}, \mathrm{Hg})_{1-x} \mathrm{Sb}_{x}(\mathrm{Se}, \mathrm{S})$ ( $x$ in the range 0.27-0.33), from Guizhou Province, China (Chen et al. 1995). The published chemical data on the later phase, however, show a large scatter, and homogeneity of the investigated material is in doubt. Pošepnýite is a member of Nickel-Strunz class 2.GB.05: Sulfides and Sulfosalts; Sulfarsenites, sulfantimonites, sulfbismuthites; Neso-sulfarsenites, etc. with additional S.

\section{Discussion concerning the independence and place of pošepnýite among complex sulfides}

In the current classification scheme, a natural group consists of isotypes to which usually several related homeotypes are added, i.e., structures with symmetry lowered by minor distortions, or by having some sites split into two or more subsites occupied by distinct species, and similar instances. Inclusion of homeotypes may be a weak point of definition, and sometimes inclusion of merotypes or even plesiotypes (Ferraris et al. 2004 and reprint of the book) may be needed, although it may quickly become questionable.

Moreover, the phylogenetic moment of zoo- and phytoclassifications is absent in mineral classification. Therefore, a mineral (a given structure) may be a member of more than one group according to what criteria are chosen - even the entire tetrahedrite group is a member of 'sphalerite-derived' structures and the 'sodalite-principle' structures, i.e., of two categories at a sufficiently high level of classification.

As stated above, pošepnýite has a general tetrahedritelike structure, with a geometry of tetrahedrally coordinated cations, antimony, and cages analogous to that in the tetrahedrite-family compounds. The principal difference from the majority of tetrahedrite species is in the population of cages and their envelopes, and the charge compensation connected with it. Because of its outstanding unique character, the homeotypic pošepnýite is a member of the tetrahedrite group sensu-lato but not a member of the tetrahedrite sensu-stricto (sub)group. What is typical for members of the sensu-stricto subgroup is the strictly maintained rule of maximally two divalent atoms $p f u$, i.e., maximally two divalent atoms per six tetrahedrally coordinated cations, so typical for tetrahedrites, tennantites, hakites etc. Moreover, this substitution of $\mathrm{Me}^{2+}$ for $\mathrm{Me}^{+}$ (including complications with $\mathrm{Fe}^{3+}$ along the substitution 
path) is disordered because of the similarity in properties and size of atomic species involved in it. Pošepnýite differs from tetrahedrites sensu-stricto in both aspects.

Pošepnýite, however, is a member of a less-tight sister subgroup positioned within the sensu-lato tetrahedrite group. In this subgroup of the tetrahedrite group, the framework has the same topology as tetrahedrite, but the population of cavities and often the character of occupation by tetrahedrally coordinated cations differ. Besides pošepnýite with a composition range of 4 (max. 4.25)-to-3 triangular-coordinated $\mathrm{Cu}$ atoms in the cavity, this subgroup (Tab. 10) contains 'end-member' goldfieldite with $4 \mathrm{Cu}$ atoms in the cavity, then galkhaite with a single $(\mathrm{Cs}, \mathrm{Tl})$ atom in the cavity, both latter phases with augmented $\mathrm{Hg}$ contents in tetrahedra in order to guarantee proper charge compensation (plus similar phases: Hg-rich vorontsovite, ideally $\mathrm{Hg}_{5} \mathrm{CuTlAs}_{4} \mathrm{~S}_{12}$ and ferrovorontsovite), and the group of five isostructural sulfosalts typified by routhierite which can be written as $\mathrm{Cu}_{2} \mathrm{Hg}_{4} \mathrm{Tl}_{2} \mathrm{As}_{4} \mathrm{~S}_{12}$. The latter have pairs of $\mathrm{Tl}$ atoms in each tetrahedrite-like cavity. Furthermore, of course, it includes kenoargentotetrahedrite, with a metal cluster in the cavity, i.e., a sulfide/alloy compound, not just sulfide. Thus, a working subgroup of 'defect/modified tetrahedrite-like structures', which represents an exciting (and may-be for materials science important) extension of the tetrahedrite structural principle. The problem just outlined touches on the elegant currently developed classification of 'sensu-stricto tetrahedrites' (Biagioni et al. 2020a) only in a few marginal points.

Stable configurations of triangularly coordinated $A$ cations in the cage of the tetrahedrite-like structure must structurally and symmetrically conform with the configuration of the inner surface of the tetrahedrite-like cage. This favors either six such cations $(\mathrm{Cu}, \mathrm{Ag})$ per cage, or a 'propeller' formed by four cations per cage, or also a minimum represented by two cations per cage, which are oppositely positioned around the central cation or vacancy. Assuming intense statistical disorder, we can also accommodate three cations per cage. Accommodation of five cations might not be favorable and, therefore, absent. Matching the size of the cage (which is augmented in the structures rich in tetrahedral $\mathrm{Hg}$ ) with the coordination requirements of cage cations is an additional problem for these cation configurations.

On the other hand, a cubic structure composed of 'tetrahedrite-like' cages is built out of tetrahedra with different sizes in practically all cases. Although, they are shared with the surrounding structure, six tetrahedra surrounding an Sb pyramid form one face of the truncated tetrahedral structure cavity. When the tetrahedrite-type structure is built by combining two conspicuously different tetrahedrally coordinated cations $(B$ and $C$ ), the cubic result will be a function of distribution of different

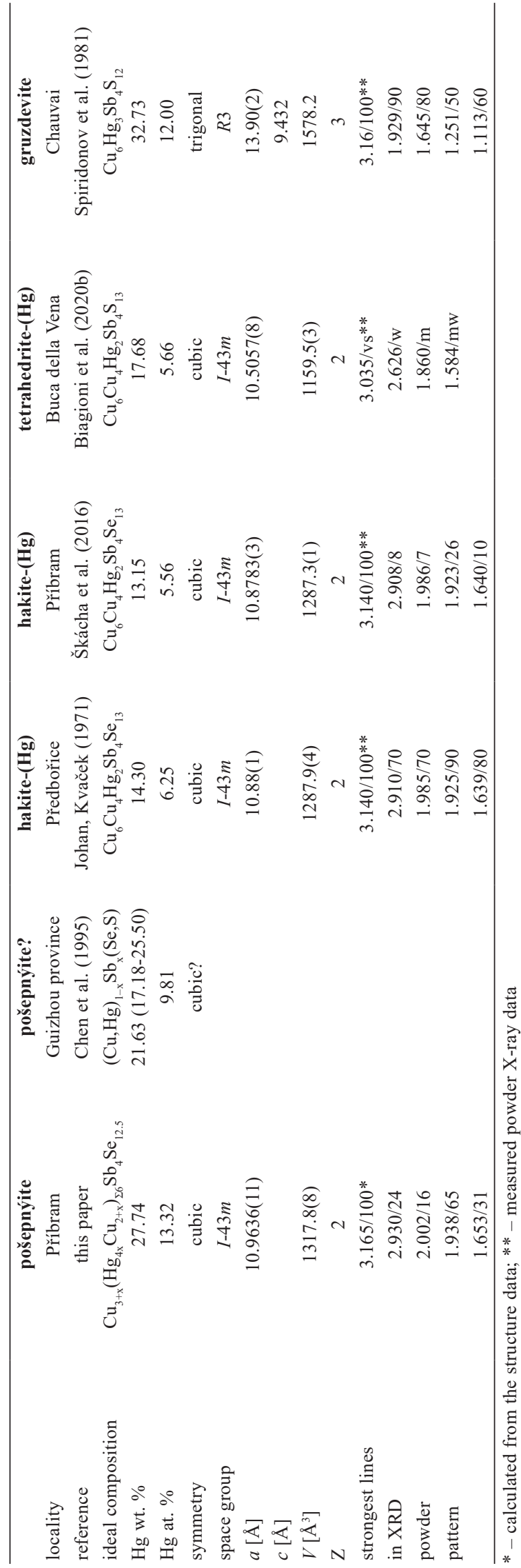


Tab. 10 Minerals belonging to the subgroup with defect/modified tetrahedrite-like structure

\begin{tabular}{|c|c|c|c|c|}
\hline Mineral/phase & Composition & Space group & Unit cell $[\AA]$ & Reference \\
\hline Pošepnýite & $\mathrm{Cu}_{6.68} \mathrm{Hg}_{2.92} \mathrm{Ag}_{0.42} \mathrm{Sb}_{4} \mathrm{Se}_{12.58}$ & $I-43 m$ & $a 10.964$ & this work \\
\hline Goldfieldite (synth.) & $\mathrm{Cu}_{10} \mathrm{Te}_{4} \mathrm{~S}_{13}$ & $I-43 m$ & a 10.266 & Makovicky, Karup-Møller (2017) \\
\hline Galkhaite & $(\mathrm{Cs}, \mathrm{Tl})(\mathrm{Hg}, \mathrm{Cu}, \mathrm{Zn})_{6} \mathrm{As}_{4} \mathrm{~S}_{12}$ & $I-43 m$ & a 10.365 & Chen, Szymanski (1981) \\
\hline Vorontsovite & $\left(\mathrm{Hg}_{5} \mathrm{Cu}\right)_{\Sigma 6} \mathrm{TlAs}_{4} \mathrm{~S}_{12}$ & $I-43 m$ & a 10.296 & Kasatkin et al. (2018) \\
\hline Ferrovorontsovite & $\left(\mathrm{Fe}_{5} \mathrm{Cu}\right)_{\Sigma 6} \mathrm{TlAs}_{4} \mathrm{~S}_{12}$ & $I-43 m$ & a 10.239 & Kasatkin et al. (2018) \\
\hline Routhierite & $\mathrm{CuHg}_{2} \mathrm{TlAs}_{2} \mathrm{~S}_{6}$ & $I-42 m$ & $a 9.978 c 11.376$ & Biagioni et al. (2014a) \\
\hline Stalderite & $\mathrm{CuZn}_{2} \mathrm{TlAs}_{2} \mathrm{~S}_{6}$ & $I-42 m$ & $a 9.865 c 10.938$ & Graeser et al. (1995) \\
\hline Arsiccioite & $\mathrm{AgHg}_{2} \mathrm{TlAs}_{2} \mathrm{~S}_{6}$ & $I-42 m$ & a 10.139 c 11.344 & Biagioni et al. (2014b) \\
\hline Ralphcannonite & $\mathrm{AgZn}_{2} \mathrm{TlAs}_{2} \mathrm{~S}_{6}$ & $I-42 m$ & $a 9.861 c 11.125$ & Bindi et al. (2015) \\
\hline Ferrostalderite & $\mathrm{CuFe}_{2} \mathrm{TlAs}_{2} \mathrm{~S}_{6}$ & $I-42 m$ & $a 9.879 c 10.849$ & Biagioni et al. (2016) \\
\hline Kenoargentotetrahedrite & $\left(\mathrm{Ag}_{6}\right) \mathrm{Cu}_{4} \mathrm{Fe}_{2} \mathrm{Sb}_{4} \mathrm{~S}_{12}$ & $I-43 m$ & a 10.492 & Rozhdestvenskaya et al. (1993) \\
\hline Synthetic & $\mathrm{Cu}_{13.8} \mathrm{Sb}_{4} \mathrm{~S}_{13}$ & $I-43 m$ & a 10.448 & Makovicky, Skinner (1979) \\
\hline
\end{tabular}

tetrahedral cations in the cage walls, and of their $\mathrm{B} / \mathrm{C}$ ratio in the structure. We think so far nobody considered this aspect of tetrahedrite-like structures, although with the incorporation of large tetrahedra, like those of $\mathrm{Hg}$, the spatial distribution of the new atomic species may be a problem, which must be solved for a $\mathrm{Cu}$-based structure. Arranging two larger tetrahedra per every six tetrahedra or four larger tetrahedra per 6 tetrahedra (i.e., two smaller tetrahedra per 6 tetrahedra) are intuitively the two best solutions for placing $\mathrm{Hg}$ tetrahedra among $\mathrm{Cu}$ tetrahedra. Three larger and three smaller tetrahedra offer another combination - an alternating arrangement of the two types (sizes). The routhierite-type structures are examples of known tetrahedron ordering in tetrahedritelike frameworks.

As a consequence, we consider cation ordering to be present and essential in pošepnýite. The pošepnýite solid-solution has one limit as ideal $\mathrm{Cu}_{3}\left(\mathrm{Hg}_{4} \mathrm{Cu}_{2}\right) \mathrm{Sb}_{4} \mathrm{Se}_{12.5}$, which represents the best tetrahedral solution as described above. Five $\mathrm{Hg}$ atoms plus one $\mathrm{Cu}$ atom per 6 tetrahedra would distort the 'ring of tetrahedra', and make structure building difficult. The opposing limit of the pošepnýite solid-solution starts at (ideally) $\mathrm{Cu}_{4}\left(\mathrm{Hg}_{3} \mathrm{Cu}_{3}\right) \mathrm{Sb}_{4} \mathrm{Se}_{12.5}$, which represents the best-fit accommodable 4-member ' $\mathrm{Cu}$ propeller' in the cavity and also secures the possibility of regular $\mathrm{Cu}-\mathrm{Hg}$ alternation around each ring of six tetrahedra. A slight excess of $\mathrm{Cu}$ above the ideal value of four in the cavity, suggested by microprobe data, is more likely to accommodate than a deficit would be. There is a composition gap (confirmed by EPMA data) between hakite-(Hg) (which has a convenient arrangement of (2 $\mathrm{Hg}+4 \mathrm{Cu}$ ) tetrahedra per 6 tetrahedra, and a '6-member propeller') and pošepnýite with a four-member propeller and the $\mathrm{Hg}$ and $\mathrm{Cu}$ tetrahedra which are arranged otherwise. Both the different occupation schemes for the cavity and the contradiction of two dissimilar $\mathrm{Cu}-\mathrm{Hg}$ arrangements in the tetrahedral framework cause the interval between hakite and pošepnýite to remain unoccupied.

Orientation variants of the local pošepnýite cation motifs will occur as local domains. Their orientation disorder will yield a bulk with cubic symmetry. In routhierite and relatives, such ordering extends over the entire structure. It gives a tetragonal result, which is conveniently connected with the fixed orientation of the Tl-Tl pair in the cavity (Fig. 34 in the overview by Makovicky 2018).

In this way, the compositional limits of pošepnýite appear to be connected with ordered accommodation of $\mathrm{Hg}$ and $\mathrm{Cu}$ tetrahedra and proper distribution/accommodation of configurations created by triangularly coordinated $\mathrm{Cu}$. This does not agree with a simple extension of the hakite formula beyond the $4 \mathrm{Cu}: 2 \mathrm{Hg}$ ratio in the tetrahedral site. Such an extension does not recognize the importance of the cation ordering aspect of the Hg-rich structure. Thus, the observed gaps and solid-solution have valid crystal-chemical reasons.

A hypothetical end-member with empty cages (vacant $A$ sites) is unrealistic. Cage-like crystal structures are always built around something of appropriate size (and fitting charge) instead of growing by themselves and being only secondarily occupied. Such a structure would only be built around neutral molecules, in a way analogous to, e.g., melanophlogite; it would form a clathrate with the neutral molecules entering its chemical formula.

Acknowledgments This work was financially supported by Czech Science Foundation (project GAČR 19-16218S) for PŠ and JS, and by the Ministry of Education, Youth and Sports National sustainability program I of the Czech Republic (project No. LO1603). Both referees, Chris Stanley and anonymous, same as handling editor František Laufek, are highly acknowledged for comments and suggestions that helped to improve the manuscript.

\section{References}

ANDERSON EB (1987) Isotopic-geochronological investigation of the uranium mineralization of Czechoslovakia. Unpublished Czechoslovak Uranium Industry Report 1962-87 
Bayliss P (2000) Glossary of Obsolete Mineral Names. Mineral Rec, pp 1-235

Biagioni C, Bonaccorsi E, Moëlo Y, Orlandi P (2014a) Mercury-arsenic sulfosalts from Apuan Alps (Tuscany, Italy). I. Routhierite, $\left(\mathrm{Cu}_{0.8} \mathrm{Ag}_{0.2}\right) \mathrm{Hg}_{2} \mathrm{Tl}\left(\mathrm{As}_{1.4} \mathrm{Sb}_{0.6}\right) \mathrm{S}$, from Monte Arsiccio mine: occurrence and crystal structure. Eur J Mineral 26: 163-170

Biagioni C, Bonaccorsi E, MoËlo Y, Orlandi P, Bindi L, D’Orazio M, Vezzoni S (2014b) Mercury-arsenic sulfosalts from the Apuan Alps (Tuscany, Italy). II. Arsiccioite, $\mathrm{AgHg}_{2} \mathrm{TlAs}_{2} \mathrm{~S}_{6}$, a new mineral from the Monte Arsiccio mine: occurrence, crystal structure and crystal chemistry of the routhierite isotypic series. Mineral Mag 78: 101-117

Biagioni C, Bindi L, Nestola F, Cannon R, Roth P, RABER T (2016) Ferrostalderite, $\mathrm{CuFe}_{2} \mathrm{TlAs}_{2} \mathrm{~S}_{6}$, a new mineral from Lengenbach, Switzerland: occurrence, crystal structure, and emphasis on the role of iron in sulfosalts. Mineral Mag 80: 175-186

Biagioni C, George LL, Cook NJ, Makovicky E, Moëlo Y, Pasero M, Sejkora J, Stanley CJ, Welch MD, Bosi F (2020a) The tetrahedrite group: nomenclature and classification. Amer Miner 105: 109-122

Biagioni C, Sejkora J, Musetti S, Velebil D, Pasero M (2020b) Tetrahedrite-(Hg), a new "old" member of the tetrahedrite group. Mineral Mag 1-26, DOI: 10.1180/ mgm.2020.36

Bindi L, Biagioni C, Raber T, Roth P, Nestola F (2015) Ralphcannonite, $\mathrm{AgZn}_{2} \mathrm{TlAs}_{2} \mathrm{~S}_{6}$, a new mineral of the routhierite isotypic series from Lengenbach, Binn Valley, Switzerland. Mineral Mag 79: 1089-1098

Chen TT, Szymanski JT (1981) The structure and chemistry of galkhaite, a mercury sulfosalt containing Cs and Tl. Canad Mineral 19: 571-581

Chen L, Li D, Wang G, Zhang Q (1995) A study of two unnamed selenide minerals. Acta Mineral Sin 15: 418-421 (In Chinese with English abstract)

Criddle AJ, Stanley CJ (1993) Quantitative data file for ore minerals, $3^{\text {rd }}$ edition. Chapman $\&$ Hall, London, pp $1-666$

Ettler V, Sejkora J, Drahota P, Litochleb J, Pauliš P, ZeMan J, NovÁK M, PAŠAvA J (2010) Příbram and Kutná Hora mining districts - from historical mining to recent environmental impact. In: IMA 2010, Budapest. Acta mineral petrogr, Field Guide Series 7: 1-23

Ferraris G, Makovicky E, Merlino S (2004) Crystallography of Modular Materials. Oxford University Press, Oxford, pp 1-370

FoIT FF JR, Hughes JM (2004) Structural variations in mercurian tetrahedrite. Amer Miner 89: 159-163

Graeser S, Schwander H, Wulf R, Edenharter A (1995) Stalderite $\mathrm{TlCu}(\mathrm{Zn}, \mathrm{Fe}, \mathrm{Hg})_{2} \mathrm{As}_{2} \mathrm{~S}_{6}$ - a new mineral related to routhierite: description and crystal structure determination. Schweiz Mineral Petrogr Mitt 75: 337-345
JOHAN Z, KVAČEK M (1971) La hakite, un nouveau minéral du groupe de la tetraédrite. Bull Soc franç minéral cristallogr 94: 381-384

Karanović Lj, Cvetković Lj, Poleti D, Balić-Žunić T, MAKOVICKY E (2003) Structural and optical properties of schwazite from Dragodol (Serbia). Neu Jb Mineral, Mh 2003: 503-520

Kasatkin AV, Nestola F, Agakhanov AA, Škoda R, Karpenko VY, Tsyganko MV, Plášil J (2018) Vorontsovite, $\left(\mathrm{Hg}_{5} \mathrm{Cu}\right)_{\Sigma 6} \mathrm{TlAs}_{4} \mathrm{~S}_{12}$, and ferrovorontsovite, $\left(\mathrm{Fe}_{5} \mathrm{Cu}\right)_{\Sigma 6} \mathrm{TlAs}_{4} \mathrm{~S}_{12}$ : the Tl- and Tl-Fe-analogues of galkhaite from the Vorontsovskoe gold deposit, Northern Urals, Russia. Minerals 8: 185

Litochleb J, Černý P, Litochlebová E, Sejkora J, Šreinoví B (2003) The deposits and occurrences of mineral raw materials in the Střední Brdy Mts. and the Brdy piedmont area (Central Bohemia). Bull mineralpetrolog odd Nár Muz 11: 57-86 (in Czech with English abstract)

Litochleb J, SeJKora J, ŠReIn V (2004) Selenide minerals from the Bytíz deposit (Př́bram uranium-base-metal ore district) Bull mineral-petrolog odd Nár Muz 12: 113-123 (in Czech with English abstract)

LYNCH JVG (1989) Large-scale hydrothermal zoning reflected in the tetrahedrite-freibergite solid solution, Keno hill Ag-Pb-Zn district, Yukon. Canad Mineral 27: 383-400

Makovicky E (2006) Crystal structures of sulfides and other chalcogenides. Rev Mineral Geochem 61: 7-112

Makovicky E (2018) Modular Crystal Chemistry of Thallium Sulfosalts. Minerals 8: 478.

Makovicky E, Skinner BJ (1979) Studies of the sulfosalts of copper. VII. Crystal structures of the exsolution products $\mathrm{Cu}_{12.3} \mathrm{Sb}_{4} \mathrm{~S}_{13}$ and $\mathrm{Cu}_{13.8} \mathrm{Sb}_{4} \mathrm{~S}_{13}$ of unsubstituted synthetic tetrahedrite. Canad Mineral 17: 619-634

Makovicky E, Karup-Møller S (2017) Exploratory studies of substitutions in a tetrahedrite/tennantite goldfieldite solid solution. Canad Mineral 55: 233-244

Makovicky E, Karanović L, Poleti D, Balić-Žunić T, PAAR WH (2005) Crystal structure of copper-rich unsubstituted tennantite, $\mathrm{Cu}_{12.5} \mathrm{As}_{4} \mathrm{~S}_{13}$. Canad Mineral 43: 679-688

MASKe S, SkInNER BJ (1971) Studies of the sulphosalts of copper. I. Phases and phase relations in the system Cu-As-S. Econ Geol 66: 901-918

MoËlo Y, Makovicky E, Mozgova NN, Jambor JL, CoOK N, Pring A, PaAr W, Nickel EH, Graeser S, KarupMøller S, Balić-Žunić T, Mumme WG, Vurro F, Topa D, Bindi L, Bente K, Shimizu M (2008) Sulfosalt Systematics: A Review Report of the Sulfosalt SubCommittee of the IMA Commission on Ore Mineralogy. Eur J Mineral 20: 7-46

Picot P, Johan Z (1982) Atlas of ore minerals. B.R.G.M., Orleans, Elsevier, Amsterdam, pp 1-458

PoŠEPNÝ F (1893) The Genesis of Ore Deposits. New York. 
Pouchou JL, PichoIR F (1985) “PAP” ( $\varphi \rho Z)$ procedure for improved quantitative microanalysis. In: ARMSTRONG JT (ed) Microbeam Analysis. San Francisco Press, San Francisco, pp 104-106

Repstock A, Voudouris P, Zeug M, Melfos V, Zhai M, Li H, KartalT, Matuszczak J (2016) Chemical composition and varieties of fahlore-group minerals from Oligocene mineralization in the Rhodope area, southern Bulgaria and Northern Greece. Mineral Petrol 110: $103-123$

RILEY JF (1974) The tetrahedrite-freibergite series, with reference to the Mount Isa $\mathrm{Pb}-\mathrm{Zn}-\mathrm{Ag}$ orebody. Miner Depos 9: 117-124

RoZhDESTVENSKAYA IV, ZAYAKINA NV, SAMUSIKov VP (1993) Crystal structure features of minerals from a series of tetrahedrite-freibergite. Mineral Zh 15: 9-17 (in Russian)

RŮŽIČKA J (1986) Minerals of the Př́bram uranium deposit. Komitét symp Horn Příbram ve vědě a techn, Příbram, 1-244 (in Czech)

SACK RO, Loucks RR (1985) Thermodynamic properties of tetrahedrite-tennantites: constraints on the interdependence of the $\mathrm{Ag}=\mathrm{Cu}, \mathrm{Fe}=\mathrm{Zn}, \mathrm{Cu}=\mathrm{Fe}$, and $\mathrm{As}=\mathrm{Sb}$ exchange reactions. Amer Miner 70: 1270-1289

SeJKora J, ŠKácha P, LAufeK F, PlášIL J (2017) Brodtkorbite, $\mathrm{Cu}_{2} \mathrm{HgSe}_{2}$, from Př́bram, Czech Republic: crystal structure and description. Eur J Mineral 29: 663-672

Spiridonov EP, Krapiva LY, Gapeev AK, Prushinskaya EY, Volgin VY (1981) Gruzdevite, $\mathrm{Cu}_{6} \mathrm{Hg}_{3} \mathrm{Sb}_{4} \mathrm{~S}_{12}$, a new mineral from the Chauvai antimony-mercury deposit, Central Asia. Dokl Akad Nauk SSSR 261: 971-976 (in Russian)

ŠKÁCHA P (2015) Role of the selenium in the late hydrothermal phase of the Príbram uranium region. MS PhD Thesis, Charles University, Prague, pp 1-235

ŠKácha P, SEJKora J (2007) Arsenolamprite occurrence in the Příbram uranium and base-metal district. Bull mineral-petrolog odd Nár Muz (Praha) 14-15: 131-133 (in Czech with English abstract)

Škácha P, Sejkora J, Litochleb J, Hofman P (2009) Cuprostibite occurrence in the Příbram uranium and base-metal district (shaft No. 16, Př́ibram - Háje), Czech Republic. Bull mineral-petrolog odd Nár Muz (Praha) 17(1): 73-78 (in Czech with English abstract)

ŠKácha P, BuiXaderas E, Plášil J, Sejkora J, Goliáš V, VLČEK V (2014) Permingeatite, $\mathrm{Cu}_{3} \mathrm{SbSe}_{4}$, from Př́ibram (Czech Republic): description and Raman spectroscopy investigations of the luzonite-subgroup of minerals. Canad Mineral 52: 501-511

ŠKÁCHA P, PláŠIL J, SEJKORA J, Goliáš V (2015) Sulphurrich antimonselite, $\mathrm{Sb}_{2}(\mathrm{Se}, \mathrm{S})_{3}$ in the Se-bearing mineral association from the uranium and base metal ore district Př́bram, Czech Republic. J Geosci 60: 23-29

Škácha P, Palatinus L, Sejkora J, Plášil J, Macek I, GoliáŠ V (2016) Hakite from Příbram, Czech Republic: Compositional variability, crystal structure and the role within the Se-mineralization. Mineral Mag 80: $1115-1128$

ŠKÁCHA P, SEJKORA J, PláŠIl J (2017a) Př́íbramite, CuSbSe ${ }_{2}$, the Se-analogue of chalcostibite, a new mineral from Př́bram, Czech Republic. Eur J Mineral 29: 653-661

ŠKácha P, SeJKora J, PlášIl J (2017b) Selenide mineralization in the Příbram Uranium and Base-Metal District (Czech Republic). Minerals 7: 91

ŠKácha P, SeJKora J, PlášIl J (2018) Bytízite, a new $\mathrm{Cu}-\mathrm{Sb}$ selenide from Př́bram, Czech Republic. Mineral Mag 82: 199-209

Wang M, Zhang X, Guo X, Pi D, YANG M (2018) Silverbearing minerals in the Xinhua hydrothermal vein-type Pb-Zn deposit, South China. Mineral Petrol 112: 85-103

Welch MD, Stanley CJ, Spratt J, Mills SJ (2018) Rozhdestvenskayaite $\mathrm{Ag}_{10} \mathrm{Zn}_{2} \mathrm{Sb}_{4} \mathrm{~S}_{13}$ and argentotetrahedrite $\mathrm{Ag}_{6} \mathrm{Cu}_{4}\left(\mathrm{Fe}^{2+}, \mathrm{Zn}\right)_{2} \mathrm{Sb}_{4} \mathrm{~S}_{13}$ : two Ag-dominant members of the tetrahedrite group. Eur J Mineral 30: 1163-1172 